\title{
Review of the Adequacy of the Fund's Precautionary Balances
}




\section{INTERNATIONAL MONETARY FUND}

\section{IMF POLICY PAPER}

\section{REVIEW OF THE ADEQUACY OF THE FUND'S PRECAUTIONARY BALANCES}

IMF staff regularly produces papers proposing new IMF policies, exploring options for reform, or reviewing existing IMF policies and operations. The following documents have been released and are included in this package:

- The Staff Report, prepared by IMF staff and completed on October 8, 2020 for the Executive Board's consideration on October 30, 2020.

The documents listed below have been separately released.

- A Press Release summarizing the views of the Executive Board as expressed during its October 30, 2020 consideration of the staff report.

The IMF's transparency policy allows for the deletion of market-sensitive information and premature disclosure of the authorities' policy intentions in published staff reports and other documents.

Electronic copies of IMF Policy Papers are available to the public from http://www.imf.org/external/pp/ppindex.aspx

\section{International Monetary Fund Washington, D.C.}




\section{INTERNATIONAL MONETARY FUND}

October 8, 2020

\section{REVIEW OF THE ADEQUACY OF THE FUND'S}

\section{PRECAUTIONARY BALANCES}

\section{EXECUTIVE SUMMARY}

Precautionary balances are a key element of the Fund's multilayered framework to mitigate financial risks. They consist of the balances in the General and Special Reserves and in the Special Contingent Account (SCA-1) and provide a buffer to protect the Fund against potential losses resulting from credit, income, and other financial risks.

The $\mathbf{2 0 2 0}$ review was postponed to allow for an assessment of the impact of the unfolding COVID-19 pandemic on Fund financial risks. Under the framework for the review, the Board sets a target and a minimum floor for precautionary balances based on a comprehensive assessment of the financial risks facing the Fund. The framework includes an indicative range of 20-30 percent for the ratio of precautionary balances to a forward-looking credit measure, but also allows for judgement.

Fund exposure and related risks have increased significantly since the last review in 2018, with trends compounded by the COVID-19 crisis. Credit outstanding has nearly doubled. Precautionary arrangements remain elevated. Lending has become more concentrated toward the largest borrower and the Western Hemisphere region. Emergency financing without ex-post conditionality has surged. Scheduled repurchases are larger and more bunched. Market-based indicators and ratings suggest a deterioration of the perceived credit quality of sovereign debt issued by the Fund's borrowers, and fundamentals are deteriorating in the riskier global environment.

Staff sees a strong case for raising the medium-term target to SDR 25 billion, and keeping it under close review. The sharp increase in demand for Fund lending in the wake of the pandemic means that the current target could fall well below the indicative range. A target of SDR 25 billion would be slightly above the midpoint of the indicative range based on likely demand using a desk survey. With uncertainty due to the pandemic still exceptionally high, the Board could revisit the target before the next regular review if warranted. If significantly higher lending demand materializes, this may well argue for another increase in the target next year.

The current pace of reserve accumulation appears adequate even if the target is raised. Subject to the aforementioned uncertainty, the approval of new financing would result in higher lending income and precautionary balances could reach the new target over the medium-term.

No change is proposed at this stage in the minimum floor of SDR 15 billion. 
Approved By

Andrew Tweedie (FIN)
Prepared by the Finance Department.

\section{CONTENTS}

INTRODUCTION

PRECAUTIONARY BALANCES AND THE FRAMEWORK FOR ASSESSING RESERVE ADEQUACY $\underline{\mathbf{5}}$
A. Financial Risks and Role of Precautionary Balances $\underline{5}$
B. Size, Composition and Coverage of Precautionary Balances $\underline{8}$
C. Framework for Assessing Precautionary Balances $\underline{11}$

DEVELOPMENTS SINCE THE LAST REVIEW $\underline{13}$
A. Credit Risk $\underline{14}$
A. Credit Outstanding $\underline{20}$
B. Income Risks $\underline{21}$
C. Financial Risks Related to Investments $\underline{24}$

ASSESSMENT OF THE ADEQUACY OF PRECAUTIONARY BALANCES 24

A. Indicative Precautionary Balances Target____ $\underline{25}$

B. The Pace of Accumulation____ $\underline{29}$

C. Minimum Floor ____ 31

ISSUES FOR DISCUSSION

\section{BOXES}

1. Typology of Fund Financial Risks and Mitigation

2. The Role of the SCA-1 in the Fund's Balance Sheet

3. Enterprise Risk Implications of Staff Proposal $\underline{30}$

\section{FIGURES}

1. Precautionary Balances Composition, Accumulation, and Coverage $\underline{10}$

2. Framework to Determine the Indicative Target and the Minimum Floor for Precautionary Balances

3. Total Commitments and Credit Outstanding: January 1995-August $2020 \_\frac{15}{16}$

4. Credit Concentration Toward Top Borrowers, 1995-2022___ $\frac{16}{17}$

5. Concentration by Region: 1995-May $2020 \ldots$

6. Credit Outstanding by Facility and Number of Approved Arrangements and RFIs___

7. Scheduled Repurchases at Current and Last Review: FY 2021-27___ $\frac{19}{20}$

8. Fund Credit and Number of Countries by Sovereign Rating Credit Category __ 20 


\section{TABLES}

1. Current versus Past Reviews: $2008-2020$

2. Forward Looking Credit Measure and Calculated Range for Precautionary Balances:

\section{ANNEXES}

I. Overview of Other IFIs' Capital Adequacy Frameworks $\underline{32}$

II. Demand for New Programs $\underline{36}$

III. Burden Sharing Capacity $\underline{39}$ 


\section{INTRODUCTION ${ }^{1}$}

1. Precautionary balances are a key element of the Fund's multilayered framework to mitigate financial risks and safeguard members' resources. They consist of three accounts, the General and Special Reserves and the Special Contingent Account (SCA-1), which provide a buffer against potential losses resulting from credit, income, and other financial risks.

2. This paper reviews the adequacy of the Fund's precautionary balances and is the first regular review since the outbreak of COVID-19. Typically conducted on a two-year cycle, the 2020 review was postponed in March to allow for an assessment of the impact of the unfolding COVID-19 pandemic on Fund financial risks. ${ }^{2}$ This paper revises and updates the paper issued on February 20, 2020 (SM/20/45, 02/20/2020). While this delay allowed staff to incorporate the initial impact of the crisis on Fund lending, the review still takes place against a backdrop of extreme uncertainty surrounding the depth of the economic crisis as well as the path and timing of global economic recovery.

3. The review uses the transparent and rules-based framework that has been employed since $\mathbf{2 0 1 0}$ to guide the assessment while also allowing for considerable judgement. At the time of the last review in January 2018, precautionary balances stood at SDR 16.8 billion, and the Board decided to keep both the minimum floor and the medium-term target for precautionary balances unchanged at SDR 15 billion and SDR 20 billion, respectively.

\section{The $\mathbf{2 0 2 0}$ review of precautionary balances complements several papers related to the} Fund's finances.

- The annual Review of the Fund's Income Position for FY 2020 and FY 2021-22 was discussed by the Board on April 27, 2020. ${ }^{3}$ On that occasion the Board agreed to maintain the margin for the rate of charge at 100 basis points over the SDR interest rate for FY 2021-22.

- A companion paper on Provisioning for Impairment Losses in the Context of the Fund discusses the role of provisioning for impairment losses in the context of the annual financial statements, and the framework developed by Fund staff for assessing the possible need for provisioning in line with the requirements of International Financial Reporting Standards (IFRS), and taking into account the unique aspects of Fund lending. Given the inter-linkages between provisioning and precautionary balances, these two papers are planned for discussion on the same day.

\footnotetext{
${ }^{1}$ Prepared by a team led by Edda Zoli comprising Kubi Johnson, Parisa Kamali, Joel Chiedu Okwuokei, and Wei Zhang, with contributions from Diviesh Nana, Breno Oliveira, Vidhya A. Rustaman, Yan Sun-Wang, Jessie Yang, and Vera Zolotarskaya, under the guidance of Christian Mumssen and Olaf Unteroberdoerster (all FIN).

${ }^{2}$ Reviews of the adequacy of precautionary balances have been on a two-year cycle since 2002 but can be brought forward by the Executive Board if needed.

${ }^{3}$ See Review of the Fund's Income Position for FY2020 and FY 2021-2022 (EBS/20/58, 4/13/20) and Review of the Fund's Income Position for FY2020 and FY 2021-2022-Supplementary Information (EBS/20/58, Sup. 1, 4/21/20).
} 
- Other periodic reviews related to the Fund's finances, including the Fund's investment account and policies related to access and surcharges are on longer review cycles, though the Board recently agreed on extending a temporary increase in annual access limits for the Rapid Financial Instrument (RFI) as part of the Fund's COVID-19 response.

5. This paper is organized as follows. The first section reviews the role of precautionary balances in the Fund's multi-layered framework for mitigating financial risks and the framework used to guide the assessment of reserve adequacy. The subsequent section takes stock of developments since the last review in 2018 , including those resulting in recent months from the still unfolding COVID-19 pandemic. The paper then assesses the adequacy of the current medium-term target of SDR 20 billion, the projected pace of accumulation of precautionary balances, and the minimum floor. The paper concludes with suggested issues for discussion.

\section{PRECAUTIONARY BALANCES AND THE FRAMEWORK FOR ASSESSING RESERVE ADEQUACY}

Precautionary balances are a key element of the Fund's multilayered framework for managing financial risks and ensuring balance sheet strength. The assessment of the adequacy of precautionary balances is anchored in a transparent and rules-based framework adopted in 2010 which also allows for judgement.

\section{A. Financial Risks and Role of Precautionary Balances}

6. The Fund faces a range of financial risks in fulfilling its mandate (Box 1$)^{4}$. Credit risk is inherent in the Fund's unique role in the international financial architecture, and is typically the predominant risk. The Fund provides financial support to members facing balance of payments difficulties, including when other financing sources may not be readily available. Lending tends to fluctuate considerably over time and concentration risk can be very high. The Fund also faces other financial risks, including income, liquidity and operational risks and has developed policies to mitigate them. Given the pass-through nature of the Fund's financing mechanism, the Fund does not face significant market (exchange rate or interest rate) risks arising from its lending. ${ }^{5}$ Nevertheless, the Fund faces financial risks related to the Fund investment activities (Box 1).

\section{Maintaining an adequate level of precautionary balances is a key element of the Fund's overall strategy for managing financial risks and ensuring balance sheet strength.} Precautionary balances are available to protect the balance sheet in the event that the Fund were to

\footnotetext{
${ }^{4}$ Financial risks are a component of the large set of enterprise risks that the Fund faces. The latter includes additional risks, such as information security, human resources, etc.

${ }^{5}$ The Fund has no exposure to exchange rate risk on its holdings of member currencies, including those representing Fund credit, or borrowings as they are all denominated in SDRs, the Fund's unit of account, and members are required to maintain the SDR value of the Fund's holdings of their currencies. The Fund does not incur interest rate risk on its credit as the rate of charge is linked directly, by means of a fixed margin, to the cost of financing (which is the SDR interest rate).
} 
suffer a loss as a result of credit, income, or other financial risks. ${ }^{6}$ In this way, they play an important role in seeking to protect the value of reserve assets that members place with the Fund and underpin the exchange of international assets through which the Fund provides assistance to members with financing needs. ${ }^{7}$

\section{Box 1. Typology of Fund Financial Risks and Mitigation}

- Credit risk refers to any borrowing member's failure to fulfill its financial obligations to the Fund. ${ }^{1}$ This risk can fluctuate widely since the Fund does not target a particular level of lending or lending growth. Credit risk is mitigated using a multilayered framework (see paragraph 7).

- Income risk is the risk that annual income will be insufficient to cover annual expenses. While the broadening of non-lending income sources under the Fund's new income model is helping mitigate this risk, currently the Fund remains dependent on lending income to cover the bulk of its activities. This risk is managed by ensuring an adequate strategy for the Investment Account, setting the margin for the basic rate of charge on Fund lending, and by the accumulation of precautionary balances, which generate investment income that buffers against income risk.

- Liquidity risk is the risk that resources will be insufficient to cover member financial needs and for the Fund to repay its obligations as they fall due, including under Fund borrowing agreements. Mitigation is through liquidity reviews in the near-term, and quota reviews and Fund borrowing over the medium-term. In addition, the Fund retains a prudential balance of quota and borrowed resources to help manage liquidity risks and provide a buffer to support the encashability of members' reserve tranche positions, and claims under borrowing, respectively. ${ }^{2}$ Liquidity is monitored daily through the Forward Commitment Capacity (FCC), which measures resources available to finance new commitments over the next 12 months.

- Financial risks related to the Fund investment activities, refer specifically to assets held in the Investment Account (IA), comprising the Endowment Subaccount (EA) and Fixed-Income Subaccount (FI). ${ }^{3}$ Market and credit risks are the primary risk factors in the investment portfolio. These risks are mitigated through high-level strategic risk parameters defined in the Board approved Rules and Regulations (Rules), additional key risk controls (e.g., credit rating threshold by asset, issuer concentration limits), and diversification requirements.

- Operational risks in financial matters refer to the risk of losses attributable to errors or omissions. These risks are mitigated through strong internal controls.

1 This can be related to, but is distinct from, risks to program performance under Fund arrangements that give rise to review delays and unmet program conditionality.

${ }^{2}$ The prudential balance is currently set at 20 percent of the quotas of members participating in the financing of IMF transactions (Financial Transaction Plan members).

${ }^{3}$ Amounts in the Fixed Income subaccount generally correspond to the Fund's reserves that are treated as precautionary balances. Article XII, section 6(f)(ii) provides that the amounts of currency transfers from the GRA to the Investment Account shall not at the time of the decision to transfer exceed the total amount of the general and special reserves.

\footnotetext{
${ }^{6}$ For instance, the Fund drew on its precautionary balances during FY 2007-08, and more recently in FY2020 to cover income losses.

${ }^{7}$ Although the Fund's gold holdings are an important factor of strength in the Fund's balance sheet, they are not included in the Fund's precautionary balances given the limitations on their use. In particular, outside of a liquidation of the Fund, the use of gold by the Fund is restricted by the Fund's Articles and any authorized use requires a decision by an 85 percent majority of the total voting power.
} 


\section{Precautionary balances are only one element of the Fund's multilayered framework for} managing credit risk. The primary tools are Fund policies on access, program design and conditionality, all of which are critical for ensuring that Fund financial support helps members resolve their balance of payments difficulties in a timely manner:

- Program design and conditionality, supported by a rigorous internal review process, are tailored to the borrowing country to help members resolve their balance of payments difficulties and address other vulnerabilities while supporting growth.

- Lending policies (standard access criteria and limits, charges, the exceptional access and early repurchase policies) are designed to discourage long or excessive use of Fund resources; safeguards assessments aim to ensure that Fund resources are adequately monitored and controlled.

- Post-Program monitoring allows the Fund to monitor and help strengthen policies affecting the repayment capacity of members with credit outstanding beyond the program period.

- The Fund's de facto preferred creditor status helps support its ability to lend when others may be unwilling or unable.

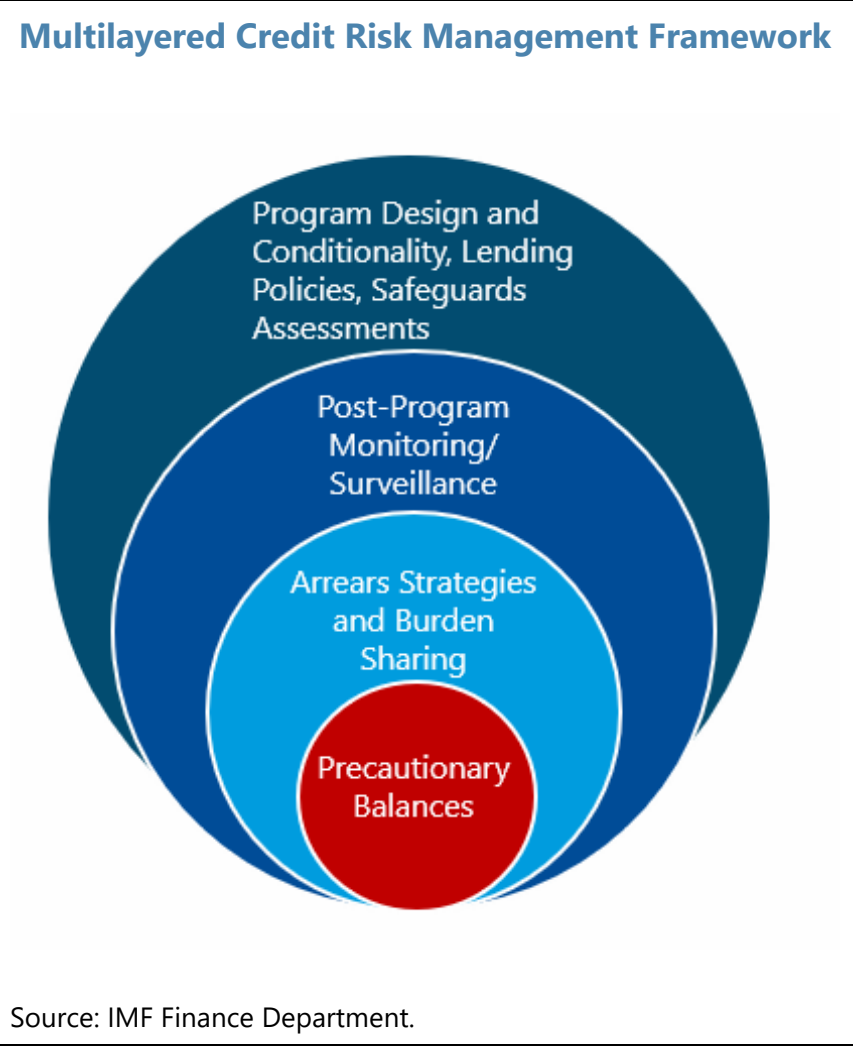

- The cooperative arrears management strategy, and the burden sharing mechanism help address arrears when they arise and limit their impact.

- Precautionary balances are available to absorb any losses that may arise from residual credit risks, notwithstanding the above elements. ${ }^{8}$

\footnotetext{
8 Precautionary balances address credit risks arising from the Fund's non-concessional lending operations, which are managed through the General Resources Account (GRA). The Fund's concessional lending operations are trust-based, so the associated credit and liquidity risks cannot impact the GRA's balance sheet.
} 


\section{B. Size, Composition and Coverage of Precautionary Balances}

\section{Precautionary balances comprise the Fund's General and Special Reserves, and the Special Contingent Account (SCA-1). ${ }^{9}$}

- Special reserve - established as a first line to absorb administrative losses. It was funded initially by the proceeds from a gold investment program, and later with net income allocations. Under the Fund's Articles, no distributions (dividends) can be made from the special reserve.

- General reserve - established to absorb capital losses and meet administrative losses. ${ }^{10}$ It has been funded through income allocations. ${ }^{11}$ Reserves accumulated in the general reserve may be distributed to members, in proportion to their quota, if the Board approves such decision by a 70 percent majority of the total voting power.

- Special Contingent Account (SCA-1) - holds contributions by members that are explicitly targeted to protect the Fund against potential credit losses resulting from the ultimate failure of a member to repay its overdue charges and repurchases in the GRA. It was funded during the period 1987-2006 mainly through the burden sharing mechanism by equal contributions from borrowing and creditor member countries via adjustments to the rates of charge and remuneration, respectively. Under existing decisions, the balances in the SCA-1 would be distributed to contributing members when there are no outstanding overdue charges or repurchases. ${ }^{12}$ As discussed in Provisioning for Impairment Losses in the Context of the Fund, the distinct nature of the SCA-1 has important implications for financial reporting under international financial reporting standards (see also Box 2).

\footnotetext{
${ }^{9}$ Precautionary balances do not include the portion of special reserves attributed to the gold profits and invested in the endowment as, in setting up the endowment, the Board recognized that its sole purpose would be to generate income. On the asset side, the Fund's reserves treated as precautionary balances are either invested in the Fixed-Income subaccount or held in SDRs and currencies.

10 Established in 1958 to absorb capital losses and to meet administrative losses, it was decided that the reserve contemplated in Article XII, Section 6(a) of the Articles, prior to the Second Amendment, would be referred to as the general reserve to distinguish it from the special reserve.

${ }^{11}$ Net operational income was placed in this reserve in FY 1958-72. Further placements of resources included net operational income generated under the Supplemental Reserve Facility (SRF), after meeting the cost of administering the PRGF Trust (FY 1998-2001); and surcharges on purchases under the SRF, credit tranches and EFF (FY 2002-2006). After a period of Fund income shortfall in FY 2007-08, the Board agreed to resume the practice of placing surcharge income in the General Reserve in FY 2011. Since FY 2016, net income has been allocated equally to the special and general reserves. The income shortfall in FY 2020 was placed to the special reserve.

12 See Executive Board Decision No. 3780-(88/12), adopted on January 29, 1988. The Board has broad discretion to decide, with a 70 percent majority, on the timing and magnitude of any SCA-1 distribution. The Board authorized such distributions in 2007 and 2019 in the context of Liberia's and Somalia's arrears clearance, respectively.
} 


\section{Box 2. Role of the SCA-1 in the Fund's Balance Sheet}

The SCA-1 differs from the special and general reserves in two main respects. First, it is intended to provide protection only against the risk posed by overdue obligations and, under current decisions, is to be distributed to members when there are no overdue obligations remaining. Second, the SCA-1 provides protection not only to the IMF's financial position, but also to its annual income. Indeed, an ultimate loss arising from overdue obligations, e.g., after a repudiation of indebtedness by a member that withdraws from the Fund, would first be charged against the SCA-1, thus insulating the Fund's income position.

As a dedicated resource to protect against credit losses, the SCA-1 has allowed the Fund to consistently report its credit balances at full face value, including for the protracted arrears cases, and remain in compliance with international financial reporting standards. Prior to the adoption of IFRS 9 in 2019, the SCA-1 helped ensure compliance with IAS 39's loss recognition requirements to the extent that its balances more than covered the amount of principal arrears to the GRA. The recent adoption of IFRS 9 for the Fund's financial statements introduced a revised impairment model under which expected credit losses have to be calculated and recognized as a credit impairment loss (if applicable) for the whole portfolio. Expected credit losses are not limited to cases of actual arrears. Staff expects that, even for large exposures, the current SCA-1 balance could be material in determining whether there is a need for the Fund to report a credit impairment.

10. Precautionary balances have more than doubled in SDR terms over the last decade but decreased somewhat last year on account of pension-related losses. Precautionary balances stood at SDR 16 billion at end-FY 2020 (Figure 1). The balance of the SCA-1, which has remained unchanged at SDR 1.2 billion since 2008, declined slightly in FY2020 after the distribution of SDR 122 million in the context of Somalia's arrears clearance, leaving the Fund's overall protection against credit risk broadly unchanged as arrears to the GRA declined by SDR 96 million. At end-FY2020 general reserves remained unchanged from the previous year at SDR 10.8 billion, while special reserves declined to SDR 4.1 billion from SDR 5.7 billion in FY 2019, reflecting a GRA income loss of SDR 1.6 billion in FY 2020, stemming mainly from the large pension related (IAS 19) expense that more than offset the net operational income. ${ }^{13}$ Overall, precautionary balances have decreased by SDR 1.7 billion in FY 2020 compared to the previous fiscal year-the first such decline in over a decade—and by SDR 0.8 billion since the last review in 2018.

11. Precautionary balance coverage ratios have fluctuated across credit cycles. The recent increase in lending has reduced the coverage by precautionary balances to about 19 percent of credit outstanding as of end-August 2020—the lowest since FY 2014 (Figure 1 and Table 1). Precautionary balances coverage of commitments has also declined to 9.1 percent. By contrast, coverage relative to the Fund's total lending capacity has remained relatively stable in recent years, at around 2.2-2.4 percent.

\footnotetext{
13 The net loss outcome for the year was greater than was projected at the time of the Review of the Fund's Income Position for FY2020 and FY 2021-2022 (EBS/20/58, 4/13/20) and Review of the Fund's Income Position for FY2020 and FY 2021-2022-Supplementary Information (EBS/20/58 Supplement 1, 4/21/20), reflecting the impact of the IAS-19 loss - see The Fund's Income Position for FY 2020-Actual Outcome (EBAP/20/62, 9/9/20).
} 
Figure 1. Precautionary Balances Composition, Accumulation, and Coverage

Composition, 2008-2020

(In millions of SDRs, end of financial year)

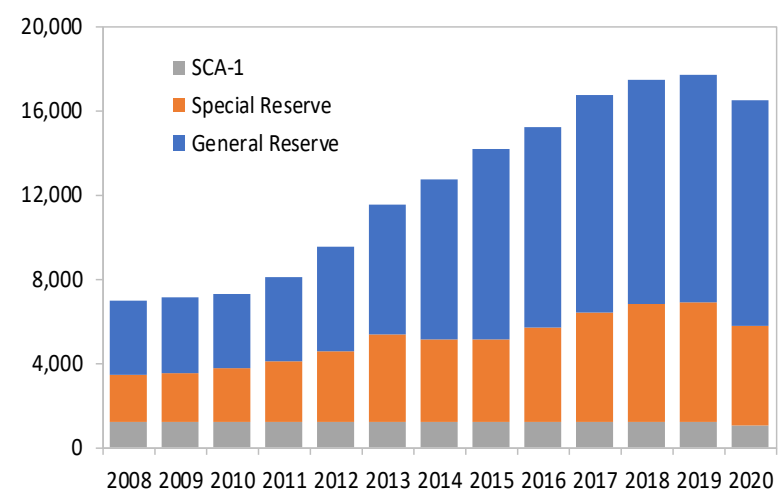

Accumulation ${ }^{1}$

(In billions of SDR)

\begin{tabular}{lccc}
\hline & FY 2019 & FY 2020 \\
\hline I Precautionary balances - beginning of period ${ }^{2}$ & 17.5 & 17.7 \\
II Operational income & 1.6 & 2.3 \\
$\quad$ Lending income including surcharges & 1.2 & 1.9 \\
$\quad$ Non-lending income & 0.4 & 0.4 \\
III Administrative expenses & -0.9 & -0.9 \\
IV Net operational income (II-III) & 0.7 & 1.4 \\
V Pension and other benefits related (IAS 19) & -0.5 & -3.0 \\
\cline { 2 - 3 } VI Precautionary balances - end of period (I+IV+V) & 17.7 & 16.0 \\
\hline
\end{tabular}

Coverage Ratios: 2001-End-August 2020

(In percent, end of financial year, unless otherwise specified)

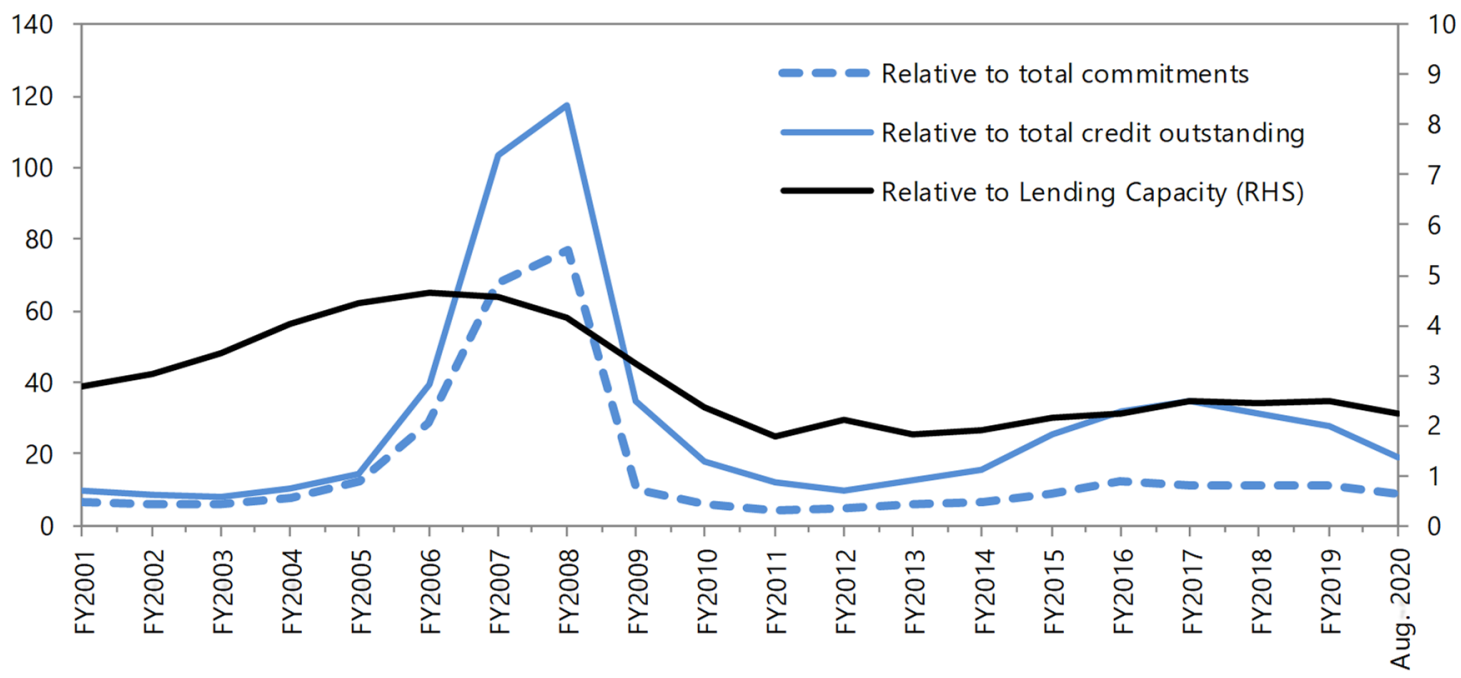

Source: IMF Finance Department.

${ }^{1}$ Components may not sum exactly to totals because for FY 2020 the distribution of SDR 122 million from the SCA-1 in the context of Somalia's arrears clearance is not shown as a separate line but included in the total.

${ }^{2}$ Includes SCA-1. 


\begin{tabular}{|c|c|c|c|c|c|c|c|}
\hline & Oct-08 & Jul-10 & Feb-12 & Nov-13 & Nov-15 & Nov-17 & Aug-20 \\
\hline \multicolumn{8}{|c|}{ (In billions of SDRs) } \\
\hline Precautionary balances & 6.9 & 7.3 & 9.2 & 12.3 & 14.5 & 16.8 & $16.0^{3}$ \\
\hline Arrears $^{2}$ & 1.1 & 1.1 & 1.1 & 1.1 & 1.1 & 1.1 & 1.0 \\
\hline \multicolumn{8}{|c|}{ Largest individual exposure } \\
\hline Actual & 5.7 & 9.0 & 17.5 & 22.2 & 16.4 & 9.6 & 31.9 \\
\hline Projected & 11.0 & 26.4 & 28.1 & 27.6 & 16.4 & 12.9 & 31.9 \\
\hline \multicolumn{8}{|l|}{ Credit outstanding } \\
\hline Actual & 17.2 & 48.6 & 88.5 & 84.1 & 51.5 & 42.7 & 85.0 \\
\hline Projected peak ${ }^{4}$ & 30.0 & 78.2 & 100.6 & 87.1 & 51.5 & 47.9 & 90.7 \\
\hline Total commitments ${ }^{5}$ & 36.5 & 144.0 & 201.6 & 189.9 & 146.0 & 137.2 & 175.7 \\
\hline Lending capacity & 165.9 & 310.1 & 451.4 & 668.7 & 665.2 & 693.4 & 712.8 \\
\hline Precautionary balances & \multicolumn{7}{|c|}{ (In percent of) } \\
\hline Credit outstanding & 40.5 & 15.1 & 10.4 & 14.6 & 28.1 & 39.4 & 18.8 \\
\hline Total commitments & 19.0 & 5.1 & 4.6 & 6.5 & 9.9 & 12.3 & 9.1 \\
\hline Lending capacity & 4.2 & 2.4 & 2.0 & 1.8 & 2.2 & 2.4 & 2.2 \\
\hline \multicolumn{8}{|c|}{$\begin{array}{l}\text { Source: IMF Finance Department. } \\
{ }^{1} \text { Review of the Adequacy of the Fund's Precautionary Balances; EBS/08/107 (12/08/2008), EBS/10/161 (8/25/2010), SM/12/63 } \\
(3 / 23 / 12), S M / 14 / 21 \text { (1/15/2014), SM/16/21 (1/16/2016), and SM/17/351 (12/27/17). } \\
{ }^{2} \text { Includes charges and principal. } \\
{ }^{3} \text { End-FY 2020. Precautionary balances rose slightly after end-FY 2020, but remain at about SDR } 16 \text { billion at the end of Q1 of } \\
\text { FY } 2021 . \\
{ }^{4} \text { Highest projected credit over January 2020-December 2031; based on existing arrangements. } \\
5 \text { Total commitments equal GRA credit outstanding plus undrawn balances. }\end{array}$} \\
\hline
\end{tabular}

\section{Framework for Assessing Precautionary Balances}

\section{The current rules-based framework for assessing precautionary balances was adopted} in 2010. ${ }^{14}$ Under this framework, the target for precautionary balances is to be broadly maintained within an indicative range linked to a forward-looking measure of credit outstanding. At the same time, the Board retains flexibility to determine where the target should be set based on a comprehensive assessment of the risks facing the Fund. While it is generally envisaged that the target will be maintained within the indicative range, there could be circumstances where the Board would decide to set or maintain a target outside the range, as was the case at the 2016 and 2018 reviews, if this is warranted by a broader assessment of financial risks. In this context, the Board has repeatedly stressed the importance of judgment.

\footnotetext{
${ }^{14}$ See Public Information Notice: IMF Board discusses the Adequacy of the Fund's Precautionary Balances (9/22/10), Review of the Adequacy of the Fund's Precautionary Balances (EBS/10/161, 8/25/10).
} 
Figure 2. Framework to Determine the Indicative Target and the Minimum Floor for Precautionary Balances

\section{Framework}

\section{- Reserve Coverage ratio:}

Set within an indicative range of 20 to 30 percent of a forwardlooking measure of credit outstanding.

\section{- Credit Measure:}

Three-year average of credit outstanding (previous 12 months and projections for the following 2 years).

\section{Judgement}

\section{Always taking into account:}

- Precautionary Arrangements

- Other considerations:

- Burden Sharing Capacity

- Concentration risks

- Correlated risks

- Arrears history

- Country risk

- Debt service profile

- Other (e.g., sustainable income)

\section{Outcome}

- Indicative Target

for Precautionary Balances

- Minimum Floor

for Precautionary Balances

Source: IMF Finance Department.

13. The framework entails several elements (Figure 2): (i) an indicative range for the reserve coverage ratio, set at 20 to 30 percent of a forward-looking measure of credit outstanding. This element draws on approaches in other IFIs (Annex I), adapted to the specific circumstances of the Fund (in particular the highly concentrated and demand-driven nature of its lending portfolio): ${ }_{i}^{15}$ (ii) a specific forward-looking credit measure to anchor the range-the three-year average of credit outstanding covering the past twelve months and projections for the next two years-which helps smooth year-to-year volatility of credit movements. ${ }^{16}$ Commitments under precautionary arrangements are excluded from the credit measure used to derive the indicative range, but are considered by the Board in setting the target; and (iii) a minimum floor to protect against an

\footnotetext{
15 The framework also has elements in common with the methodologies used by rating agencies in assessing capital adequacy in supranational lending institutions (see Annex II in Review of the Adequacy of the Fund's Precautionary Balances (SM/16/21, 1/26/16)).

${ }^{16}$ The two-year projection is based on scheduled net disbursements under existing non-precautionary arrangements. The methodology does not require an explicit analysis of possible future arrangements or for delays in scheduled disbursements or early repurchases. Scenario analysis can be used to indicate how the indicative range would be affected by different projections, which in turn can inform Board judgment.
} 
unexpected increase in credit risks, particularly after periods of low credit, and ensure a sustainable income position. ${ }^{17}$

\section{Based on this framework, the Board has increased the target for precautionary} balances twice and the minimum floor once. The Board agreed in 2010 to raise the indicative medium-term target by SDR 5 billion to SDR 15 billion in light of the sharp increases in commitments and actual and projected lending, the projected increases in individual exposures, and the limited capacity of the burden sharing mechanism. The target was further increased to SDR 20 billion in 2012, and reaffirmed in 2014, 2016 and 2018, even though the target exceeded the indicative range in the last two reviews. A minimum floor of SDR 10 billion for precautionary balances was agreed in 2010 and reaffirmed in the 2012 and 2014 reviews. The floor was increased to SDR 15 billion in 2016 as this

\begin{tabular}{|c|c|c|}
\hline \multicolumn{3}{|c|}{$\begin{array}{l}\text { The Floor and Target Agreed at } \\
\text { 2010-18 } \\
\text { (In billions of SDRs) }\end{array}$} \\
\hline Review year & Floor & Target \\
\hline Before 2010 review & - & 10 \\
\hline 2010 & 10 & 15 \\
\hline 2012 & 10 & 20 \\
\hline 2014 & 10 & 20 \\
\hline 2016 & 15 & 20 \\
\hline 2018 & 15 & 20 \\
\hline
\end{tabular}
was seen as more consistent with maintaining a sustainable income position in the medium term and would also provide a larger buffer to protect against risks associated with any unexpected rise in credit. The floor was reaffirmed in 2018.

\section{The framework applies to precautionary balances as a whole. The Board has not} adopted separate targets for the sub-components, i.e., balances in the special and general reserves and the SCA-1. The appropriate distribution of net income between the special and general reserves is considered by the Board each year as part of the annual review of the Fund's income position. The Board has not had an explicit discussion of the role and level of balances in the SCA-1 for several years. Depending on Directors' views on this paper and also taking account of the informal discussion on provisioning, staff could come back to this topic at a later date.

\section{DEVELOPMENTS SINCE THE LAST REVIEW}

Credit risks have increased significantly since the last review, and the lending portfolio has become more concentrated toward the largest borrower notwithstanding a surge in emergency financing in the wake of COVID-19. The Fund's near-term income risks remain moderate to low but are subject to increased uncertainty. Investment risks and uncertainty have increased.

\footnotetext{
${ }^{17}$ While Fund credit is highly volatile and can increase sharply, it takes a considerable time to rebuild precautionary balances. Thus, the floor provides a buffer in the face of an unexpected increase in credit risks. The floor is kept under review in light of changing conditions and longer-term trends in Fund lending.
} 


\section{A. Credit Risk}

16. Credit outstanding has risen sharply and is on a substantially higher trajectory than projected at the time of the last review. After declining by about 60 percent from the crisis peak, Fund credit has almost doubled since mid-2018, driven mainly by two factors: (1) drawings under Argentina's Standby arrangement approved in June 2018, and cancelled in July 2020, for a total of SDR 31.9 billion, and (2) demand for emergency financing in the wake of the outbreak of the COVID-19 pandemic. The bulk of the latter consists of disbursements under the RFI for 32 members for a total of SDR 14.7 billion, approved between March and end-August 2020. ${ }^{18}$ Emergency financing also includes disbursements under existing arrangements that were augmented as well as drawings under existing precautionary arrangements by 3 countries for a total of SDR 2.5 billion. The rise in new financing has more than offset some sizable advance repurchases, notably by Greece, the largest borrower at the time of the last review, and Portugal. ${ }^{19}$

\section{At this point, credit outstanding appears likely to at least match the previous peak following the global}

financial crisis. At end-August 2020, credit outstanding stood at nearly SDR 85 billion, compared to SDR 43 billion at the time of the last review. Based on current arrangements as of end-August, 2020, credit outstanding is expected to peak in FY 2022 at about SDR 88.5 billion, close to the maximum level reached in FY $2011-12 .{ }^{20}$ Compared to the last review, the projected credit path has increased by an average of about SDR 43 billion over the period FY 2021-24.

\section{Total commitments have also increased significantly. Total} commitments stood at nearly

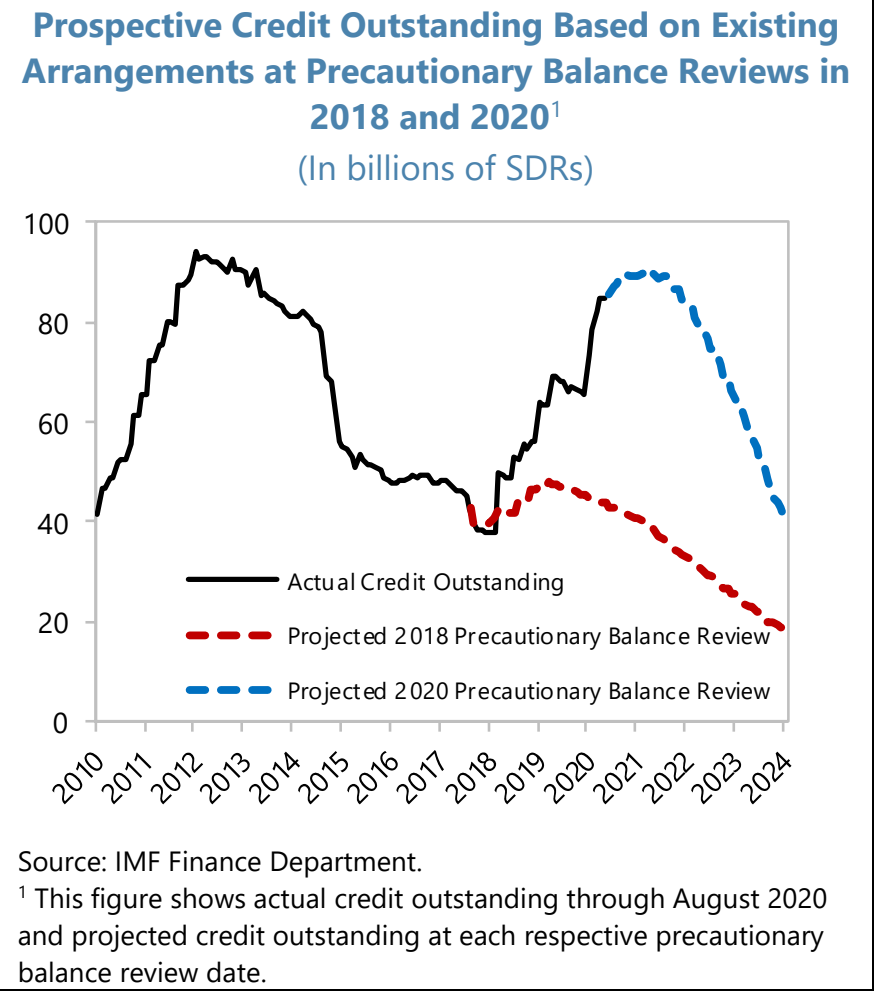

Prospective Credit Outstanding Based on Existing 2018 and $2020^{1}$ (In billions of SDRs) SDR 176 billion at end-August 2020, compared to about SDR 137 billion at the time of the last review (Figure 3). This includes undrawn balances under existing arrangements as well as

\footnotetext{
${ }^{18}$ These include the GRA portion of blends with Rapid Credit Facilities.

${ }^{19}$ Fund credit outstanding to Greece declined from SDR 9.5 billion in November 2017 to SDR 4.6 billion at end-August 2020. Fund credit to Portugal, which stood at SDR 5.4 billion in November 2017, was fully repaid.

20 Throughout the paper-unless otherwise indicated - baseline projections for credit, income, precautionary balances, and other relevant variables are based on the assumption that purchases and repurchases under existing active non precautionary arrangements will take place as scheduled.
} 
commitments under precautionary arrangements, including the new FCL arrangements for Chile and Peru. $^{21}$

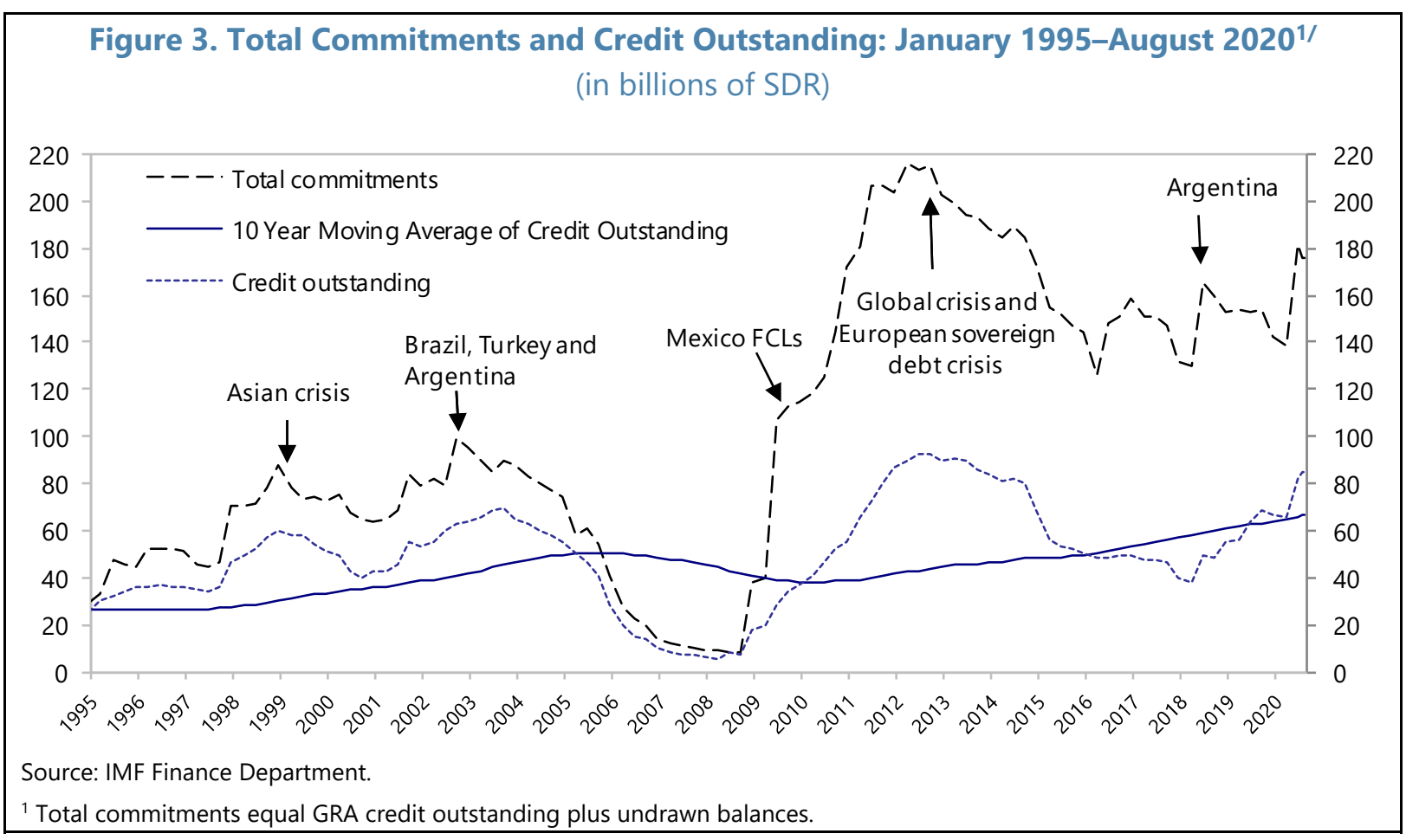

\section{Concentration of the loan portfolio toward the largest borrower remains elevated.}

Credit concentration to the largest borrower stood at 38 percent as of end-August 2020, down from a recent peak of 48 percent at end-2019 (Figure 4, panel B). The share of outstanding Fund credit toward the five largest borrowers (currently, Argentina, Egypt, Ukraine, Pakistan and Greece) stood at 73 percent as of end-August 2020, close to the historical average. It has fallen significantly since March 2020 with the surge of lending for emergency financing amidst the coronavirus crisis. ${ }^{22}$ Credit concentration to the largest five borrowers is expected to decline further as additional loans are disbursed (Figure 4, panel A).

\footnotetext{
${ }^{21}$ In November 2019 and May 2020, the IMF Board approved successor two-year arrangements for Mexico and Colombia under the FCL, respectively. Two additional FCL arrangements for Peru and Chile, for a total of about SDR 25 billion were approved in May 2020. In September 2020, the IMF Board approved the augmentation of the Colombia's FCL for SDR 6.5 billion.

22 At end-August 2020 the Fund's exposure to Argentina amounted to SDR 31.9 billion. Exposure to Egypt was SDR 12.1 billion, including SDR 2 billion under the RFI facility. The other three largest exposures include SDR 7.9 billion to Ukraine; SDR 5.6 billion to Pakistan, including under a new extended arrangement approved in July 2019 and under the RFI; and SDR 4.6 billion to Greece. 31 GRA programs with exceptional access were approved over the period 2008-18. Egypt's purchase under the RFI in 2020 entails exceptional access due to outstanding credit under the previous Extended Fund Facility.
} 
Figure 4. Credit Concentration Toward Largest Borrowers, 1995-2022

A. Credit Concentration Toward Largest Five Borrowers ${ }^{1 /}$

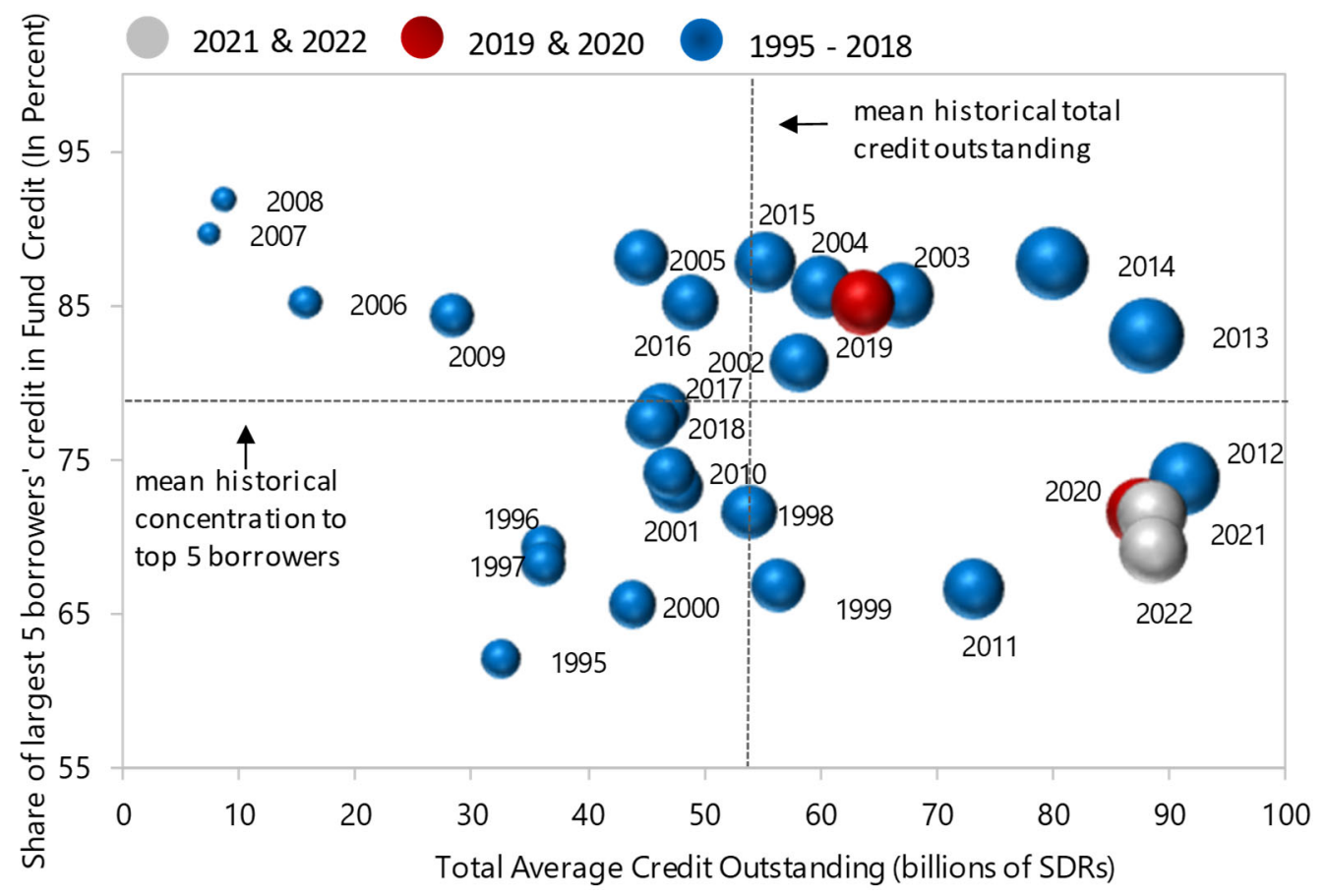

B. Credit Concentration Toward Largest Borrower2/

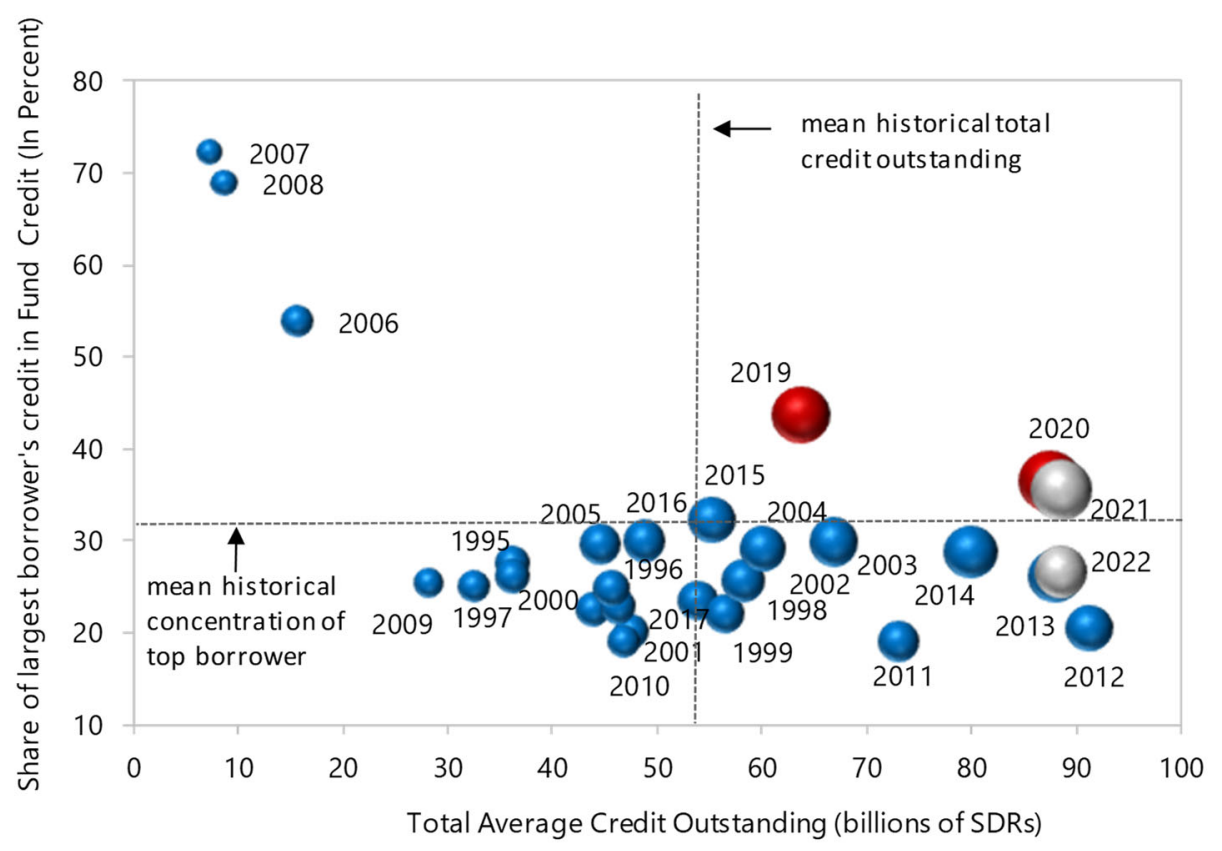

${ }^{1}$ The relative size of the bubbles reflects the amount of Fund credit outstanding to the largest five borrowers.

${ }^{2}$ The relative size of the bubbles reflects the amount of Fund credit outstanding to the largest borrower. 
20. Regional concentration has shifted from Europe to the Western Hemisphere. Given the Fund's crisis lending role, regional concentration of credit is often high and tends to fluctuate across economic cycles. Since the last review, lending exposure to euro area countries has declined considerably to about 5 percent of Fund credit in August 2020, compared to 45 percent in November 2017 (Figure 5, left panel). At the same time, exposure to the Western Hemisphere has climbed to about 43 percent of total Fund credit, mainly on account of the arrangement with Argentina. On a commitment basis (i.e., including the FCL arrangements with Chile, Mexico, Colombia, and Peru) exposure to this region is even higher (at about 66 percent of Fund's outstanding credit and undrawn GRA balances) (Figure 5, right panel). Lending to the Middle East and Central Asia has remained fairly elevated, representing nearly 29 percent of Fund credit. Overall regional concentration-as measured by the Herfindahl index on outstanding Fund's credit-remains similar to the last review. ${ }^{23}$

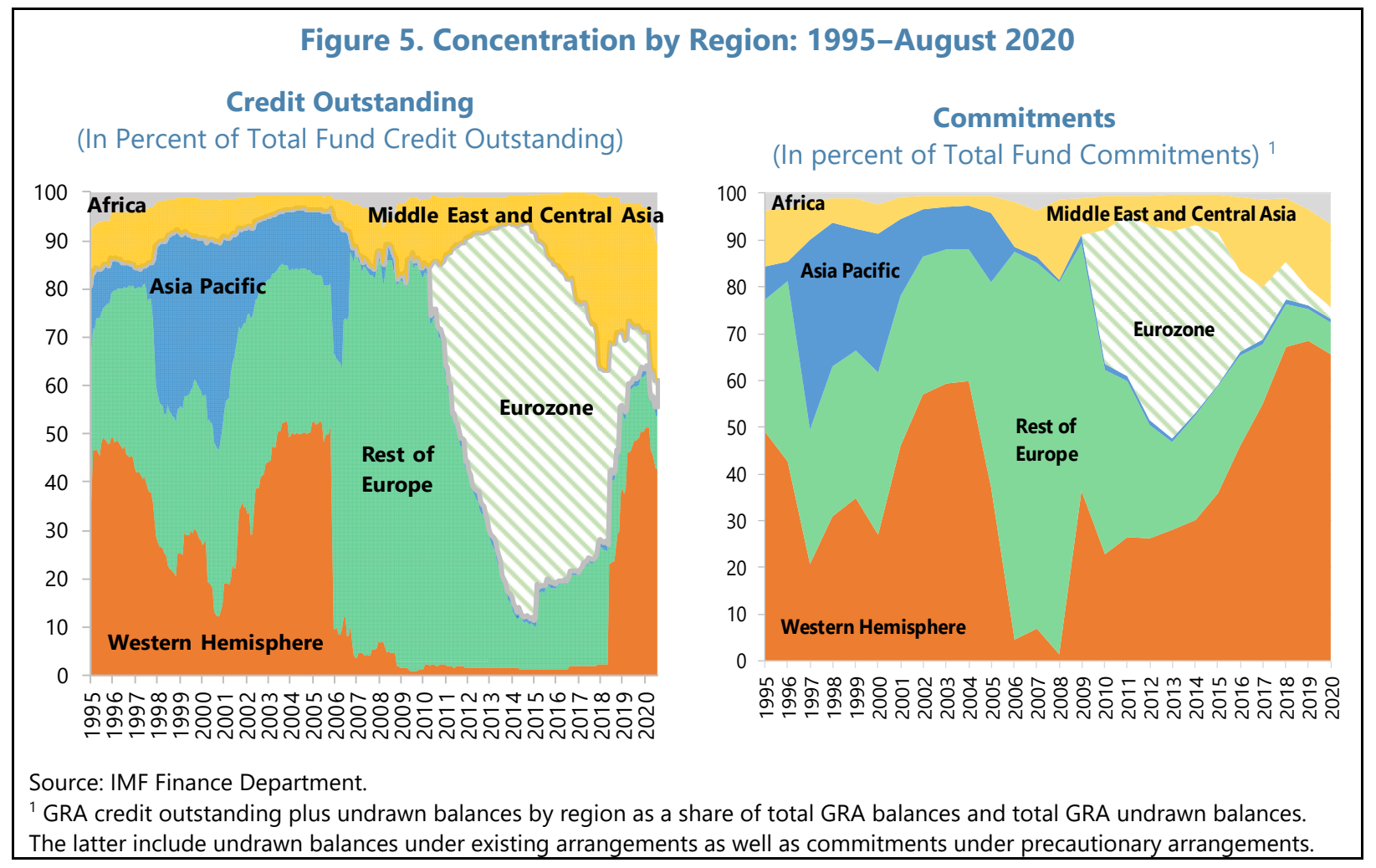

\section{COVID-19 has led to an unprecedented increase in the share of the credit portfolio} accounted for by emergency financing instruments. As of end-August 2020 the share of RFI financing surged to nearly 17 percent of the Fund's lending portfolio (Figure 6). This is by far the highest share since the RFI was created in 2009, with the SDR amount approved in 2020 about 16 times as much the highest annual amount approved before the pandemic.

\footnotetext{
23 The Herfindahl-Hirschman index is a statistical measure of concentration, computed as the sum of the squares of the shares of the credit outstanding toward each region to total credit outstanding. It takes values between 0 and 1. As of August 2020, regional concentration was 0.29 , slightly lower than at the time of the last review.
} 
Figure 6. Credit Outstanding by Facility and Number of Outstanding Arrangements and RFIs Credit Outstanding by Facility Number of Outstanding Arrangements and RFIs
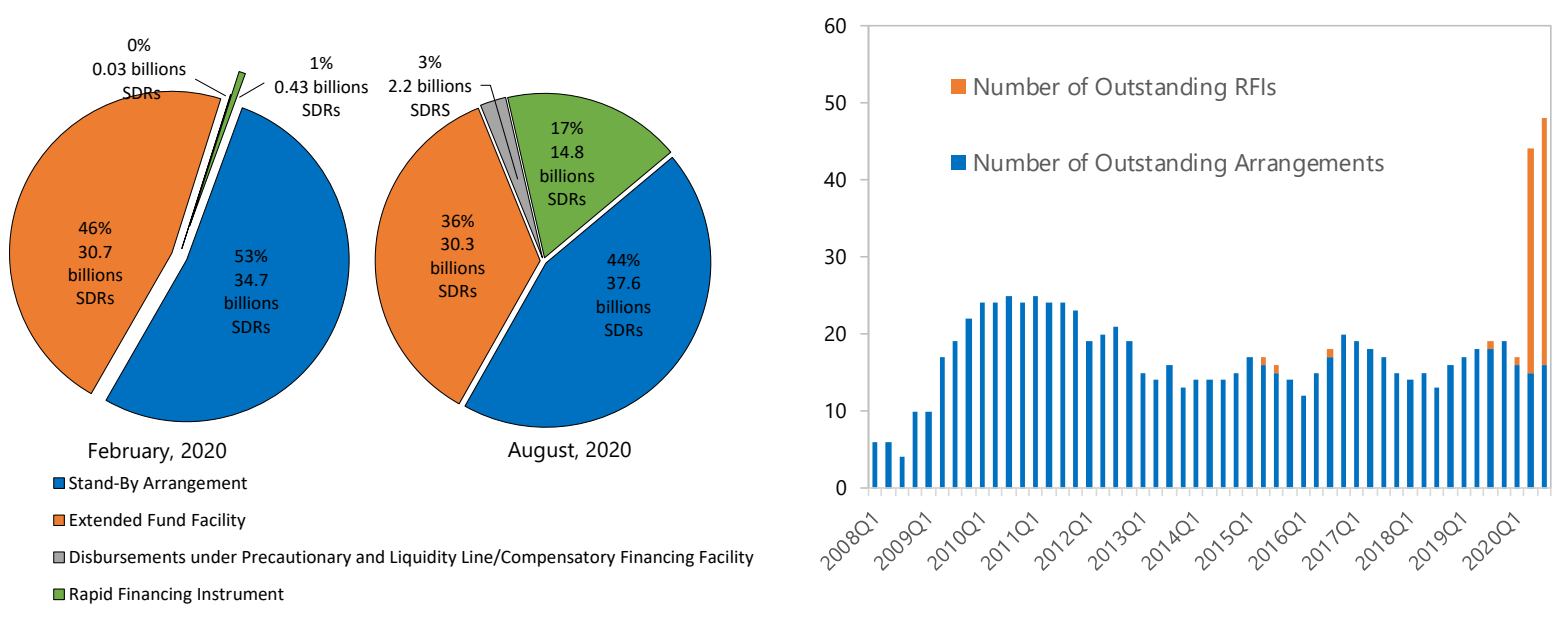

Source: IMF Finance Department.

22. Credit concentration risks are heightened by a sharp jump in repurchases falling due in the coming years (Figure 7). Total scheduled repurchases jump sharply to about SDR 63 billion in FY 2023-25, compared to about SDR 21 billion in FY 2020-22. ${ }^{24}$ This is about SDR 42 billion more than projected for those years at the time of the last review and reflects both scheduled repurchases by Argentina and repurchases associated with the recent surge in one-off RFI disbursements. Argentina's repurchases alone account for SDR 15.5 billion and SDR 10.3 billion in FY 2023 and FY 2024, respectively. Historically, such large repurchases in SDR terms from a single borrower have been rare-the highest scheduled repurchases by an individual borrower

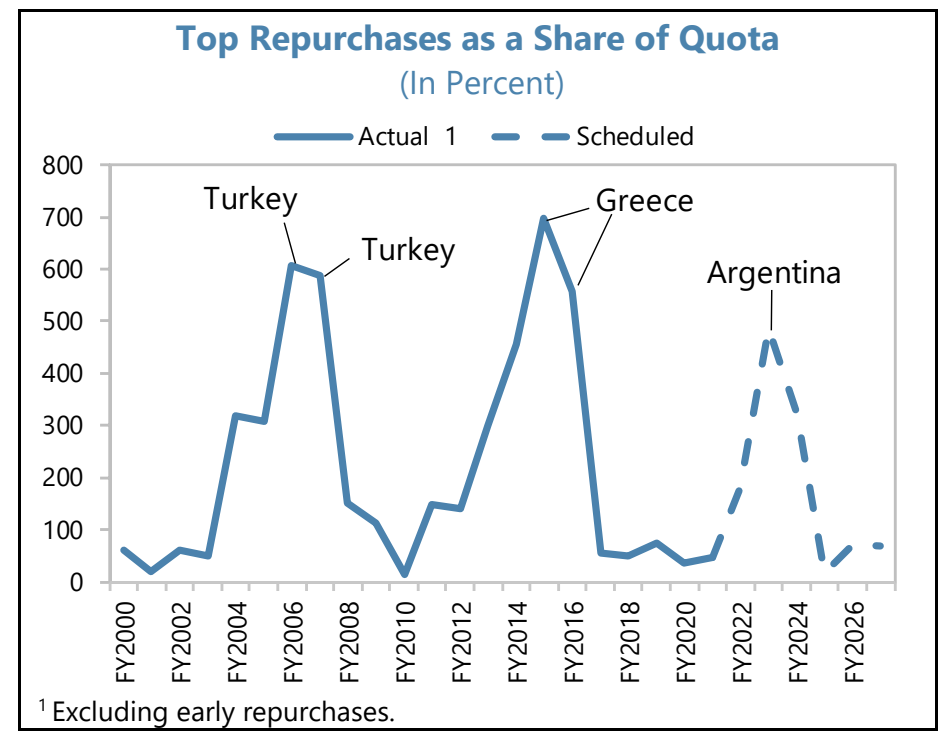
since FY 2000 included those by Brazil in FY 2004 for SDR 9.6 billion, and Greece in FY 2015 for SDR 7.7 billion. ${ }^{25}$ Relative to the country's economic size, as proxied by quota, Argentina's scheduled repurchases for FY 2023-24 are also large, although a few other borrowers have made repurchases

\footnotetext{
24 The average maturity of the Fund's loan portfolio, weighted by share in outstanding credit, reached 4.5 years in 2015 but has since declined to 3.2 years in August 2020. This is close to the average maturity of slightly over 3 years prevailing in the wake of the global financial crisis.

${ }^{25}$ The two largest advance repurchases since FY 2000 were those by Brazil in FY 2006 for SDR 14.2 billion and by Ireland in FY 2015 for SDR 15.7 billion.
} 
of a similar or even larger share of their quota since FY 2005. Repurchases of single-tranche RFIs disbursements account for about SDR 15 billion, with the bulk scheduled in FY 2024-25.

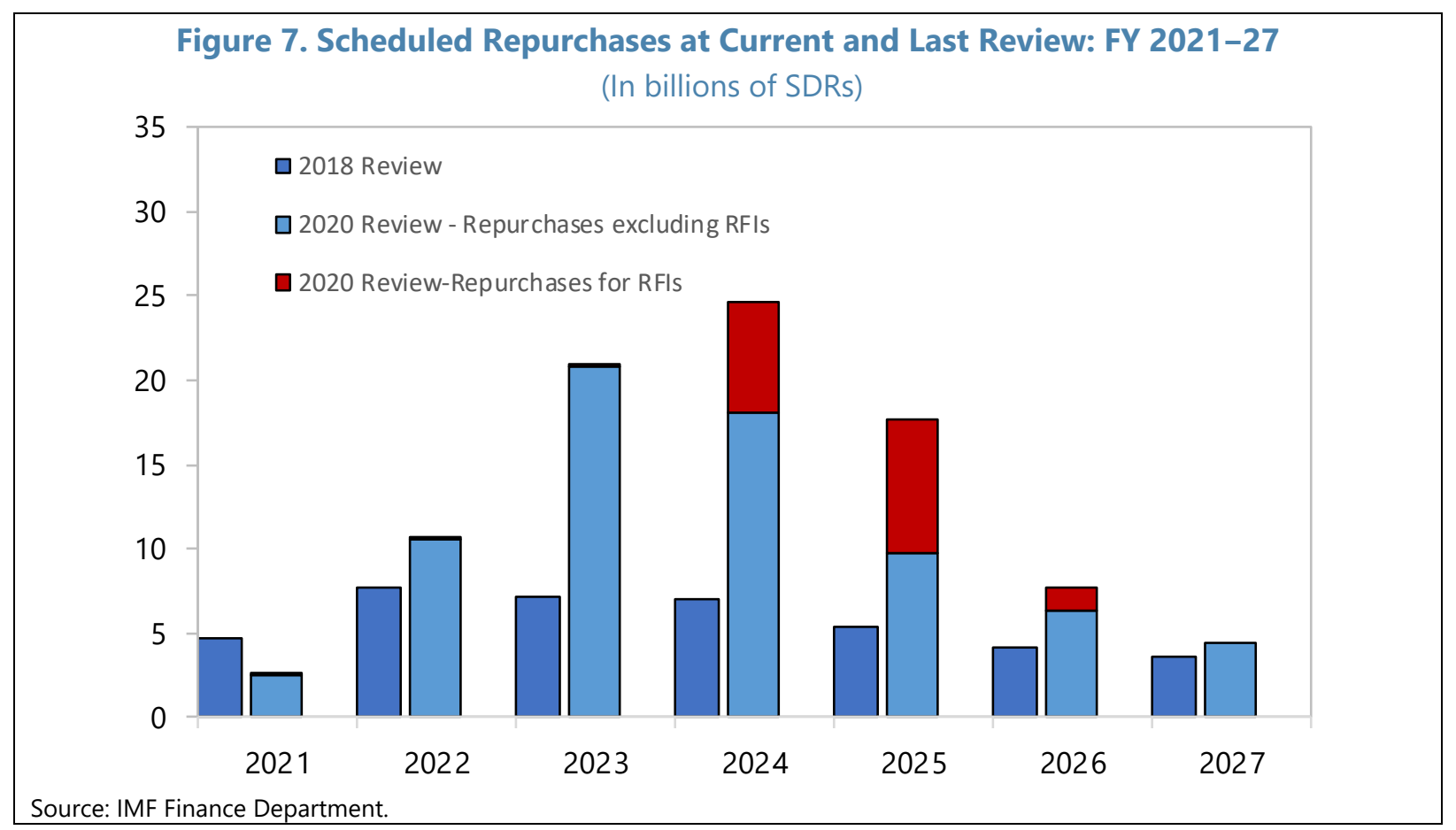

23. Arrears to the GRA were reduced after Somalia cleared its overdue obligations in March 2020. As of end-August 2020, protracted arrears to the GRA of Sudan, the only country remaining in arrears to the Fund, amounted to nearly SDR 1 billion, including principal arrears of about SDR 0.2 billion, which are more than covered by existing balances in the SCA -1 . There have been no new cases of protracted arrears since the last review.

24. In line with previous Board guidance, staff does not apply internal credit ratings for the purpose of assessing the adequacy of precautionary balances. Rather, the framework provides room for Board judgment on the level of risk embodied in the current loan portfolio when determining the precautionary balances target. To help inform this judgment, staff has analyzed publicly available sovereign credit ratings and market-based indicators such as sovereign bond spreads. Such indicators reflect perceptions of risks facing private investors, which cannot be translated directly to assess credit risk faced by the Fund given its unique role. Moreover, these risks may diverge significantly when a Fund borrower undergoes a private debt restructuring. Nonetheless, monitoring such indicators can be useful to the extent that the factors affecting the perceived ability of sovereigns to repay private creditors could also have a bearing on their ability to repay the Fund.

\section{The weighted average of sovereign credit ratings of the Fund's borrowers has} deteriorated significantly since the last review. The average sovereign credit rating of the Fund's borrowers, weighted by Fund outstanding credit in each rating category, has been on a downward trend since 2016, and has now reached levels above those observed in 2002 at the time of several 
major crises in emerging market economies (Figure 8, left panel) ${ }^{26}$ In this context, Fund lending to member countries rated less than BB- by leading rating agencies stood at about SDR 69 billion at end-August 2020 (nearly 85 percent of total Fund credit to rated countries), up from about SDR 28 billion at end-November 2017 (73 percent of total Fund credit to rated countries). This deterioration was already evident before the eruption of the COVID-19 pandemic and may become more acute as the coronavirus crisis creates more severe and lasting global economic spillovers. It mainly reflects larger exposures to member countries with relatively lower or deteriorating sovereign credit ratings. The number of Fund borrowers rated less than BB- has also spiked recently with sharp increase in emergency lending and the broader unfolding of the pandemic crisis (Figure 8 , right panel). ${ }^{27}$

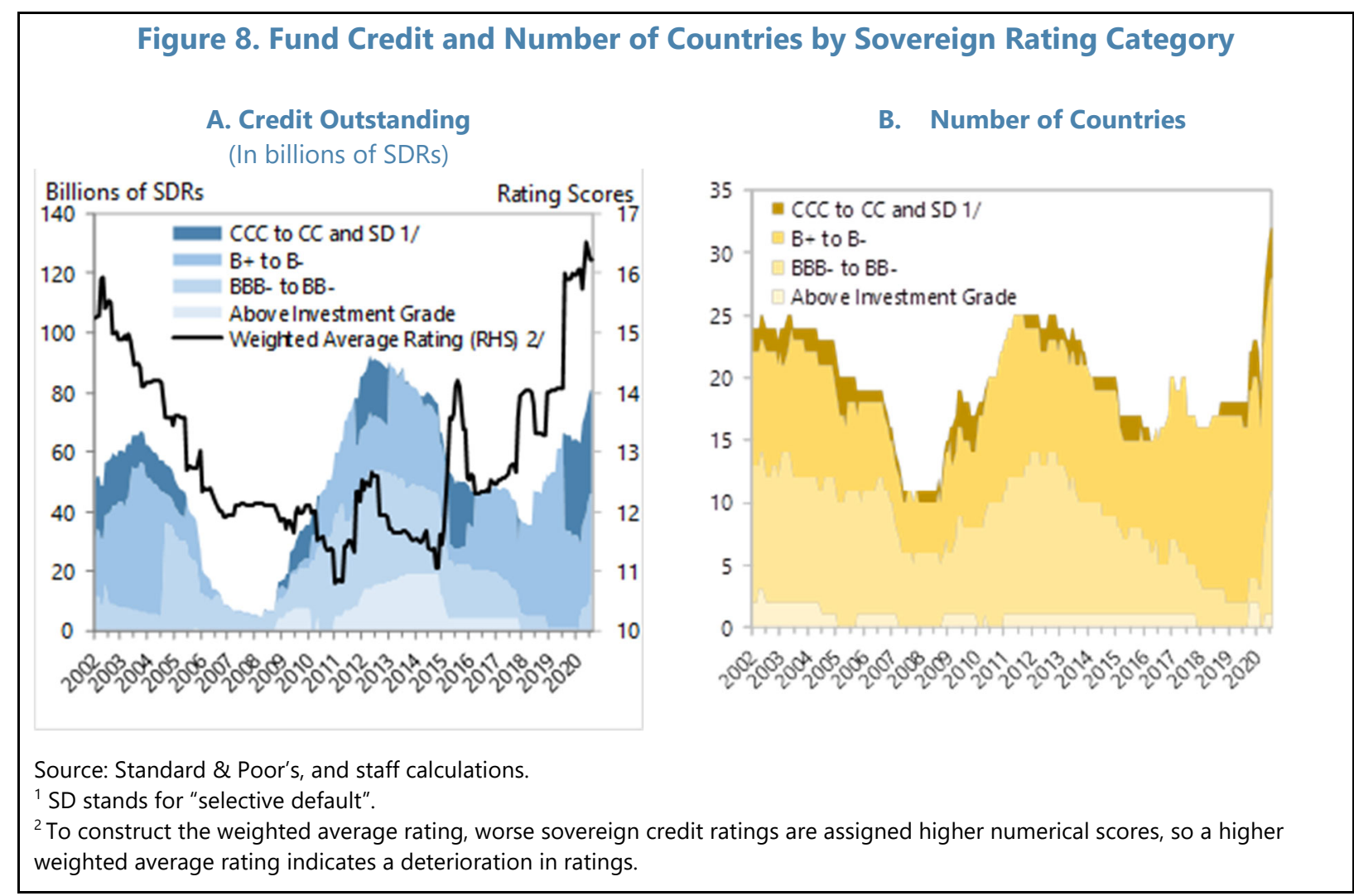

\footnotetext{
${ }^{26}$ Figure 8 shows the weighted average rating and Fund credit by sovereign rating category based on Standard \& Poor's ratings; similar trends are evident if the ratings from Moody's or Fitch are used instead.
}

27 If Argentina is excluded, the weighted average rating of the Fund portfolio would point to a more modest deterioration since the last review. 
26. Spreads on sovereign debt issued by the Fund's borrowers, weighted by the Fund's credit portfolio, have also increased sharply since the last review, largely on account of perceived credit risks emanating from the Fund's largest

borrower. The weighted average of the sovereign spreads of the Fund's largest five borrowers (accounting for 73 percent of total credit outstanding) first spiked in the Fall of 2019 and surged to new heights following the coronavirus outbreak, driven by a hike in Argentina's spreads. Spreads have declined recently, although they remain at historical highs, as Argentina restructured its FX denominated debt with private creditors and announced its intention to negotiate a new arrangement with the IMF.

\section{B. Income Risks}

\section{The Fund's near-term} risks that annual income would be insufficient to cover annual

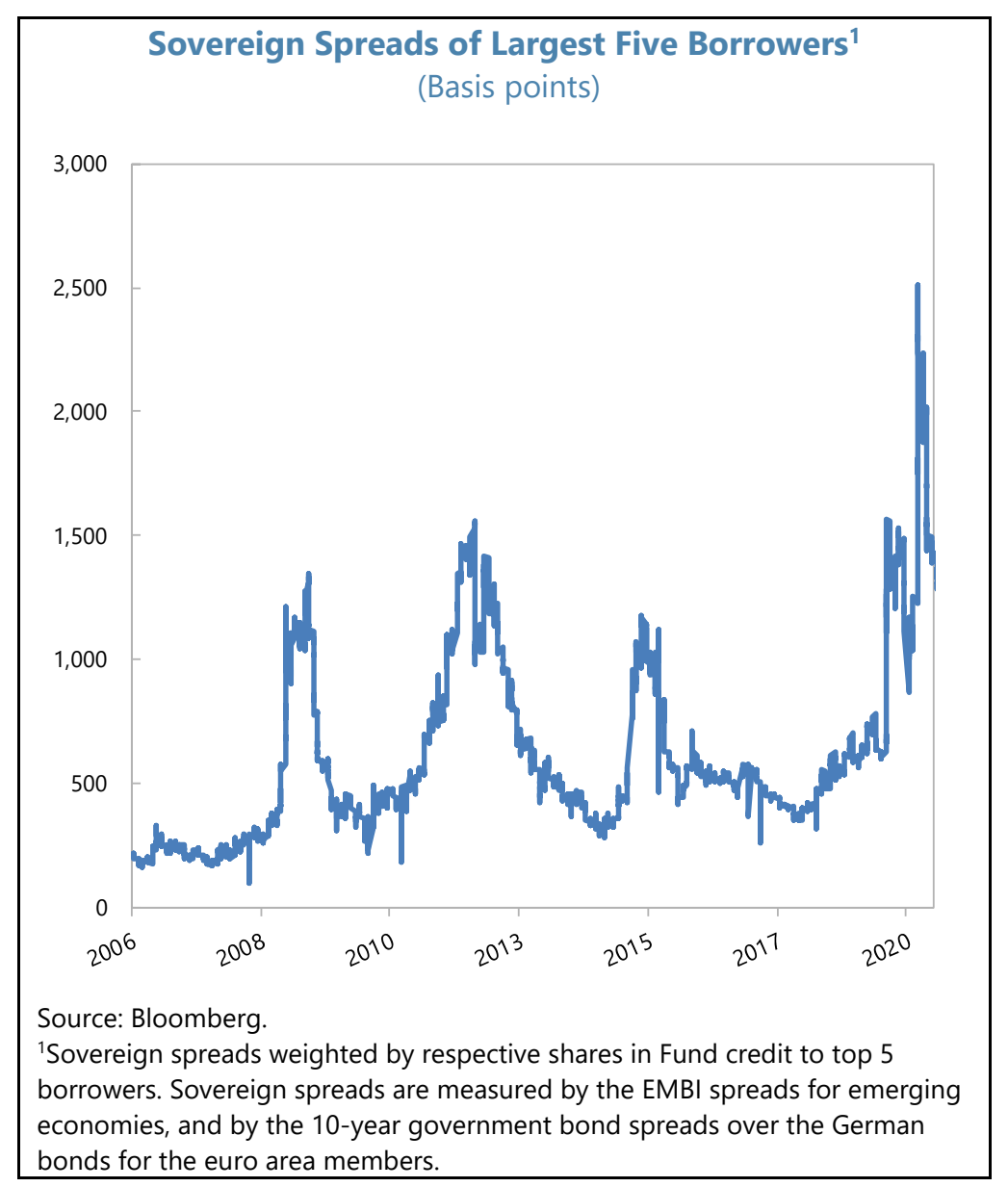
expenses remain moderate to low, but are subject to increased uncertainty. ${ }^{28}$ Even assuming no additional arrangements, staff projections suggest that total operational income, excluding the impact of any pension-related (IAS 19) gains or losses, would exceed total expenditures by a wide margin, averaging about SDR 1.4 billion annually in the three-year period through FY 2023 (Figure 9). Projected lending income has increased significantly compared with the prior review reflecting mainly the new GRA arrangements approved since January 2018 and the surge in emergency financing demand since the outbreak of the pandemic. The higher projected lending income is partly offset by moderately lower projections for investment income over the medium term, mainly reflecting the lower projected path for interest rates. At the same time, expenses are projected to trend slightly higher in SDR terms reflecting the strengthening of the U.S. dollar against the SDR and the recently revised net administrative budget in real U.S. dollar terms. While the projected operating income margin has increased significantly, it remains subject to the increased concentration risks discussed above. Of the average lending income projected through FY 2023, about 41 percent is accounted for by the Fund's largest borrower and nearly another 41 percent by the next four top borrowers.

\footnotetext{
${ }^{28}$ The current baseline projection is compared to the baseline projections presented in the 2018 Review of the Adequacy of the Fund's Precautionary Balances (SM/17/351, 12/27/17).
} 
Figure 9. Medium-Term Projected Operational Income and Expenses: 2021-251

(In millions of SDRs, end of financial year)

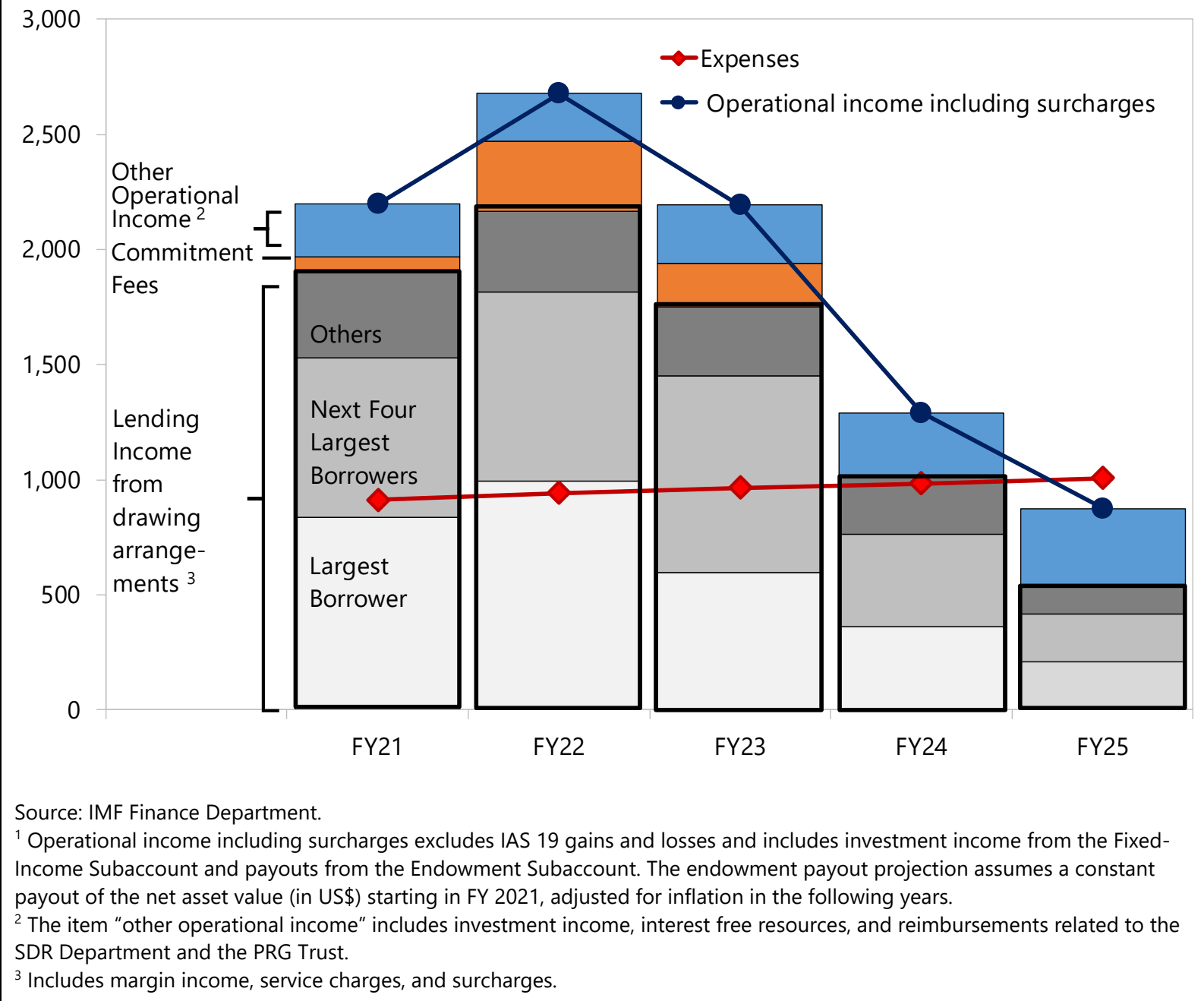

28. Key risks to Fund income associated with recent developments include: (i) cancellations and changes in the timing of purchases under existing arrangements; (ii) fluctuations in the annual pension-related gain or loss as determined under IAS 19; (iii) and uncertainties around the global interest rate environment and U.S. dollar/SDR exchange rate path. The risk of cancellation or rephasing of purchases under existing arrangements is expected to be mitigated by other members seeking additional sources of funding as the crisis unfolds, which may also reduce the level of concentration risk somewhat. The broadening of non-lending income sources is helping mitigate income risk; however, the low interest rate environment is expected to diminish contributions from investment income in the near term. This downside risk of diminished returns may extend into the medium term. Other valuation adjustments also contribute to uncertainty around the baseline projection: 
- Recognition of pension-related gains and losses under IAS 19: ${ }^{29}$ Since the adoption of the amended IAS 19 in FY 2014 and the elimination of the option to defer recognition of a portion of gains and losses on the Fund's employee benefits plan over time, the Fund's annual income has been subject to significant volatility. The gains or losses are mainly driven by the periodic re-measurement of the defined benefit obligation-which is highly sensitive to small variations in the discount rate-and by changes in the fair value of the Plan assets. ${ }^{30} \mathrm{FY} 2020$ pension-related (IAS 19) losses amounted to about SDR 3 billion, attributable mainly to the impact of the discount rate change on the Fund's defined benefit obligation (DBO) and performance of Plan assets during the year. The discount rate declined by 113 bps since the beginning of the year, to a low of 2.73 percent at the end of FY 2020, inflating the DBO significantly; and Plan assets performance was negative for the year reflecting a decline across asset classes in the portfolio.

- Impairment recognition under IFRS 9: Under the new accounting standard for impairment (IFRS 9) adopted for the Fund's financial statements in FY 2019, it is no longer necessary for a credit event to occur to recognize credit losses. Instead, entities are required to estimate expected credit losses (ECL) based on a probability-weighted assessment of a range of possible future outcomes. The application of IFRS 9 to the Fund portfolio takes into consideration the unique aspects of Fund lending and its financial safeguards, including the burden sharing mechanism and balances in the SCA-1. Under IFRS 9, if the risk of a member entering into protracted arrears increases significantly, a provision for an impairment may need to be recognized at an earlier stage than under the previous standard. However, no such adjustments have been recognized to date.

\footnotetext{
${ }^{29}$ IAS 19 is the International Financial Reporting Standard that deals with accounting for pension and other employee benefits. For further discussion, see Review of the Fund's Income Position for FY2020 and FY 2021-2022 (EBS/20/58, 04/13/20) and Review of the Fund's Income Position for FY2020 and FY 2021-2022-Supplementary Information (EBS/20/58, Supplement 1,04/21/20).

${ }^{30} \mathrm{~A}$ one percent increase (decrease) in the discount rate yields a decrease (increase) of about SDR 1.7-1.9 billion in the Fund's defined benefit obligation. See Review of the Fund's Income Position for FY2020 and FY 2021-2022 (EBS/20/58, 04/13/20).
} 


\section{Financial Risks Related to Investments}

29. Financial risks related to the investment assets of the Endowment Subaccount and the Fixed-Income Subaccount have increased since the last report. The Endowment Subaccount (EA) and the Fixed Income (FI) subaccount have distinct investment objectives and pursue different strategies accordingly. Highlights of relevant developments related to the investment strategies and the outlook for risk and returns are as follows.

- FI investments. A greater portion of the $\mathrm{Fl}$ is being invested in line with the expanded $\mathrm{FI}$ investment strategy as the planned 5-year phase-in of longer duration investments is approaching completion in FY 2021. As a result, the average duration of Fl investments has increased gradually to 1.2 years (from 0.7 years). With the decline in SDR yields to historical lows following central bank policy responses to the COVID-19 outbreak, overall FI returns are expected to be compressed going forward in line with the lower level of interest rates. Excess returns above the 3-month SDR rate are expected to remain positive over the short to medium term although lower yield levels provide less protection against rising interest rates. Staff's risk return projections under the scenario that yields remain unchanged or rise in line with market forward expectations suggest that downside risks are likely to remain moderate over a 1-year horizon.

- EA investments. The Board approved refinements to the EA's strategic asset allocation in March 2018 aimed to improve risk return trade-offs. The refinements have resulted in a slightly shorter duration of 5.5 years (compared to around 7-8 years previously) and an increase in equity allocation by 5 percent. In addition, the Board endorsed a 5 percent allocation into private infrastructure debt which will be gradually implemented starting in the first half of FY 2021. The March 2018 review also established a framework for future EA payouts, with a delay in payouts for three years. For the EA, risks to the return outlook have increased materially following the impact on market conditions of the COVID-19 outbreak. Achieving the long-term return target of 3 percent real return in US dollar terms remains increasingly challenging under the current market conditions given very low yield levels, elevated equity valuations and considerable uncertainty associated with the impact of COVID-19 on economies and asset classes.

\section{ASSESSMENT OF THE ADEQUACY OF PRECAUTIONARY BALANCES}

Credit exposures and associated risks have increased significantly. Taking into account the expected surge in demand for Fund lending, the current target for precautionary balances of SDR 20 billion is likely to fall below the indicative range in this and the next fiscal year. Hence, staff proposes that the medium-term target be raised to SDR 25 billion for now, and be kept under close review given exceptionally high uncertainty on the global economic fallout from the pandemic. With the projected increase in lending income, the pace of reserve accumulation would also increase and remain adequate at this time, even if the target was raised. 


\section{A. Indicative Precautionary Balances Target}

30. Under the baseline scenario based solely on existing arrangements, the current target for precautionary balances of SDR $\mathbf{2 0}$ billion is still within the forward-looking indicative range. Under the agreed framework, the starting point for assessing precautionary balances is a forward-looking measure of average credit outstanding over three years. Based solely on existing arrangements, the measure would peak at about SDR 83 billion in FY 2021. ${ }^{31}$ This is some SDR 38 billion higher than at the time of the previous review in end-November 2017 (Table 2, column 1). This scenario assumes no new arrangements in addition to those approved as of endAugust 2020; purchases and repurchases are made as scheduled; and there are no drawings under existing precautionary arrangements. In this scenario, the calculated indicative range is from about SDR 17 to nearly 25 billion in FY2021, with the midpoint at about SDR 21 billion, up from about SDR 11 billion at the last review (Table 2, columns 2-4).

\section{Taking into account the impact of the pandemic on further demand for Fund} programs, the target could fall below the indicative range in this and the next fiscal year. Staff has considered three additional scenarios envisaging additional demand for non-precautionary Fund programs to help countries deal with the fallout from the pandemic:

- One scenario is based on a desk survey of potential demand for Fund lending, which reflects desk assessments of the likelihood of a program request based on knowledge of member countries' economic outlook, financing needs, and political landscape. Under this scenario, 15 countries would enter a new Fund-supported program in FY 2021-22 for a total of about SDR 50 billion. The indicative range would increase to between SDR 19 billion and 29 billion, with the current target for precautionary balances only slightly above the bottom of the range. Given the high likelihood of additional loan demand related to the global pandemic, staff considers this a more relevant scenario than the baseline of no new programs.

- Under another scenario, using model-based estimates consistent with the October 2020 WEO baseline, new demand for Fund programs, including successor arrangements, could reach nearly SDR 138 billion over FY 2021-22 and could raise the indicative range to between SDR 23 billion and SDR 35 billion in FY 2021 (see Annex II for details).

- Under a more adverse scenario than the October 2020 WEO baseline, which could be illustrative of the impact of a second wave of the pandemic, new demand for Fund programs could reach nearly SDR 202 billion (see Annex II for details). In addition, all current FCL arrangements are assumed to be fully drawn, for a total of SDR 82 billion in disbursements. As a result, average Fund credit outstanding would increase by another SDR 137 billion over the WEO baseline and peak at SDR 302 billion, over 3 times the historical peak observed in the wake of the global financial crisis. In this scenario, the indicative range would rise to between around

\footnotetext{
${ }^{31}$ Such measure calculates the average of credit outstanding over the past 12 months and projections over the next 24 months.
} 
SDR 39 billion and SDR 59 billion in FY 2021, which is nearly double to three times the SDR 20 billion target.

Table 2. Forward Looking Credit Measure and Calculated Range for Precautionary Balances: 2010-2022 1

(In billions of SDRs, end of financial year)

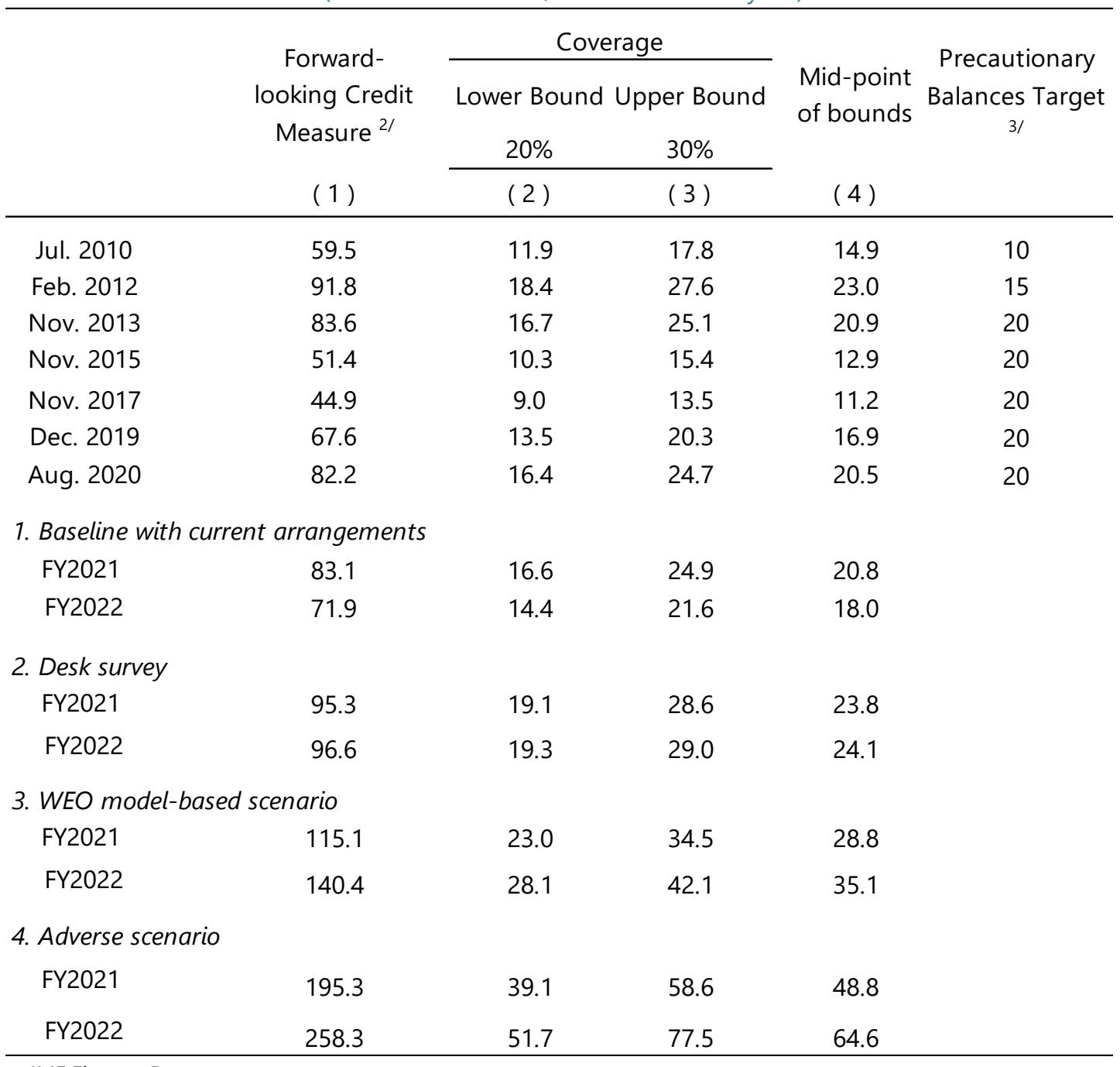

Source: IMF Finance Department.

${ }^{1}$ Figures from Jul. 2010 to Nov. 2017 reflect calculations at the time of past reviews (see EBS/10/161, 8/25/2010; SM/12/63, 3/23/2012; SM/14/21, 1/15/2014; SM/16/21, 1/26/16; and SM/17/351, 12/27/2017). Figures for FY 2020-21 are based on projections.

${ }^{2}$ Three-year average of past 12 months average and projections 2 years forward.

${ }^{3}$ Before review completion.

32. In addition to the significant increase in the indicative range based on forward-looking credit measures, several other risk-related considerations point to the merits of further bolstering the Fund's precautionary balances:

- Elevated concentration risks: As noted above, the Fund's loan portfolio has become much more concentrated toward the largest borrower, with credit outstanding to Argentina alone now reaching $1 \frac{1}{2}$ times the current SDR 20 billion target. The higher concentration risks are 
compounded by a heavy bunching of scheduled repurchases in the next few years as well as significant challenges facing Argentina's economy, exacerbated by the COVID-19 crisis. ${ }^{32}$ Also, market-based indicators point to a deterioration of the perceived average credit quality of the sovereign debt issued by the Fund's borrowers. Regional concentration has increased as well, making the Fund's loan portfolio more vulnerable to possible correlated risks affecting Latin America (see also below).

- Surge in RFIs: At end-August 2020, about 17 percent of the Fund's portfolio consisted of oneoff emergency purchases, whose repurchases are bunched in FY 2024-25. This share could increase further if more emergency financing is approved. Given that RFIs are not subject to upper credit tranche (UCT) conditionality, and that the fallout from COVID-19 remains highly uncertain, associated risks are higher than usual.

- Heightened COVID-19 related uncertainty. The global environment is riskier and economic fundamentals of many Fund borrowers are expected to deteriorate. A more permanent shift in risk fundamentals cannot be ruled out. As discussed in the October 2020 Fiscal Monitor, the COVID-19 outbreak and its financial and economic consequences will cause a major increase in fiscal deficits and public debt ratios in many countries, and, as emphasized in the October 2020 Global Financial Stability Report, vulnerabilities are rising, most notably in non-financial corporates and sovereign sectors. In this environment, especially if it were to persist, balance of payments financing may remain under strain for several Fund borrowers and their credit risks buffers are likely to narrow.

- Level and concentration of precautionary arrangements: Commitments under the Fund's precautionary arrangements remain elevated at about SDR 78 billion as of end-August 2020, slightly higher than the SDR 76 billion at the last review. Under the framework, these commitments are not included in the calculation of the forward-looking credit measure, but are taken into account judgmentally when setting the precautionary balances target. That said, one PLL arrangement was fully drawn and all four FCL arrangements are now concentrated in one region, suggesting that the probability of significant correlated drawdowns can no longer be

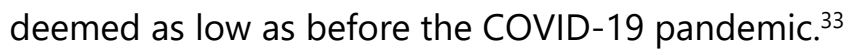

\footnotetext{
32 Argentina completed a restructuring of its FX denominated debt with private creditors in September 2020. Financial conditions, however, remain very fragile. The authorities have maintained an active policy dialogue with Fund staff and made explicit their intention to seek a new Fund-supported program (IMF Press release 20/287, https://www.imf.org/en/News/Articles/2020/08/26/pr20287-argentina-argentine-government-notifies-imf-requestnew-fund-arrangement). The authorities have also committed to continue to honor Argentina's obligations to the Fund.

${ }^{33}$ At the time of the last review the probability of drawing under these precautionary arrangements was assessed to be low, given the low historical incidence of drawings (see Annex $\mathrm{V}$ in Review of the Adequacy of the Fund's Precautionary Balances (SM/16/21, 1/26/16) for a detailed discussion). This remains staff's assessment, notwithstanding Colombia's recent announcement that it intends to make a partial drawing under the FCL for budget support later in the year.
} 
- Very low burden sharing capacity: The Fund's burden sharing capacity has declined to new lows. The burden sharing mechanism plays a key role in protecting the Fund's income position in the face of unpaid charges by members in arrears (Annex III). Since the last review, the capacity of the mechanism, which had improved somewhat in FY 2019-20, primarily on the back of a rise in the remunerated reserve tranche positions, fell again with declining SDR rates. The current residual capacity of about SDR 23 million, taking account of existing arrears by Sudan, remains very low relative to projected charges coming due over the coming year. For example, charges due in FY 2022 by the Fund's five largest borrowers' amount to about SDR 1.9 billion. The emergence of new unpaid charges could thus have a sizeable negative impact on Fund income.

- Continued large credit capacity. While not formally part of the framework for setting the indicative target, Directors have agreed to include credit capacity among the indicators for assessing where to set the precautionary balances target. The rationale is that Fund lending can change rapidly, so credit outstanding may be a poor indicator of future credit risk. The Executive Board has in past reviews discussed a precautionary balances target to credit capacity ratio of 6 percent. ${ }^{34}$ Applying this ratio to the Fund's current credit capacity of US $\$ 1$ trillion would yield an indicative target of more than SDR 40 billion, more than double the current target. ${ }^{35,36}$ Moreover, it cannot be ruled out that an increase in the Fund's credit capacity may be required if

\footnotetext{
${ }^{34} \mathrm{At}$ the 2002 Review, before the current framework on the adequacy for precautionary balances was adopted, staff had argued that the assessment of the adequacy of the Fund's precautionary balances should be geared primarily to the Fund's credit capacity because of the Fund's ability to lend to individual members in large absolute amounts, cumulatively up to its credit capacity. At that time staff had proposed to aim for a ratio of precautionary balances to credit capacity of 6 percent (The Fund's Policy on Precautionary Financial Balances, EBS/02/185, 11/01/2002). The Board urged staff to develop a more comprehensive analytical framework to take into account credit capacity, credit concentration, and credit outstanding.

35 The Fund's lending capacity consists of the Fund's total usable resources, before any lending, less relevant prudential balances, and currently amounts to close to US\$1 trillion.

${ }^{36}$ On January 16, 2020, the Board approved a doubling of the NAB to a total of credit arrangements of SDR 364.7 billion, which is expected to become effective January 1, 2021, and a new NAB period through end-2025. With a view to maintaining the Fund's overall resource envelope, on March 31, 2020 the Board approved a framework for a new round of bilateral borrowing, to succeed agreements currently in place through end-2020.
} 
downside risks materialize and the global economic fallout from the COVID-19 pandemic deepens.

\section{Given these considerations, staff believes there is a strong case for raising the} indicative medium-term target for precautionary balances to at least SDR $\mathbf{2 5}$ billion. The appropriate size of the increase comes down to judgment and timing. Staff could see a reasonable case for raising the target to SDR 25-30 billion. Raising the target to SDR 30 billion would bring it close to the midpoint of the indicative range derived from the model-based forward-looking credit measure, and could be further justified based on other qualitative risk considerations discussed above. However, such a large increase would be predicated on the assumption of significant additional lending, which may not materialize. Given this uncertainty, staff sees merit in initially increasing the target to SDR 25 billion. This would be at the top of the indicative range under the baseline (with only existing arrangements) and would bring it slightly above the midpoint of the indicative range under the scenario based on the desk survey. Given the exceptional uncertainty surrounding the expected demand for Fund lending and increased credit risks, staff would keep the situation under close watch, and come back to the Board before the next regular review if a further increase in the target was warranted by developments. ${ }^{37}$

\section{B. The Pace of}

\section{Accumulation}

\section{Under all lending scenarios,} precautionary balances would reach the current SDR 20 billion target by

FY 2022-23. At end-FY 2020,

precautionary balances stood at

SDR 16.0 billion, compared with a projected level of SDR 17.6 billion at the time of the 2018 review. Under staff's baseline projection-incorporating the new arrangements approved through August 31, 2020, and assuming an unchanged charges and fee structure-precautionary balances would reach SDR 20 billion by end-FY 2023. These projections abstract from the impact of potential future pension-related IAS19 gains or losses, or changes in the balances of the SCA-1 related to possible arrears clearance. ${ }^{38}$

\footnotetext{
37 The impact of further changes to lending and other policies in response to COVID-19 could also be assessed in this context, taking into account the specific modalities and duration of any proposals.

${ }^{38}$ As the SCA-1 is a dedicated resource to protect against risks posed by overdue obligations, if Sudan's arrears were cleared, any remaining SCA-1 balances would be distributed in the absence of any new GRA arrears (see Executive
} 


\section{The proposed SDR 25 billion target would be reached in FY 2026 under the desk} survey scenario. Approval of new financing beyond the desk survey would result in higher lending income and a faster accumulation of precautionary balances, such that the proposed target of SDR 25 billion would be exceeded by the end of FY 2024 under the scenario consistent with the October 2020 WEO baseline and in FY 2023 in the more adverse scenario. Conversely, under the current arrangements scenario, precautionary balances would peak at slightly above the current target SDR 20 billion target. In the more adverse scenario, also assuming full drawdown of existing FCLs, precautionary balances would reach over SDR 46 billion in the medium term.

\section{Box 3. Enterprise Risk Implications of Staff Proposal ${ }^{1 /}$}

The proposals of this paper are expected to improve the Fund's enterprise risk profile by mitigating financial, budget, strategic, and reputational risks. The higher medium-term target for precautionary balances is expected to boost the Fund's credit risk buffers, a crucial mitigation against risk amid growing credit exposure and concentration, as well as a deteriorating debt and growth outlook for many current and potential borrowers, given the Fund's lending mandate. Higher credit risk buffers would also better position the Fund in its efforts to step up engagement with members affected by the pandemic, thus mitigating strategic and reputational risks. Furthermore, higher precautionary balances would mitigate potential risks to the Fund's income position related to both portfolio and operational risks, reducing risks to the mediumterm budget. The Board's option to revisit the target before the next review and consider another increase in the target also constitutes a mitigation against further downside risks related to the exceptionally high uncertainty due to the pandemic. Residual risks remain, given the unprecedented challenges posed by the current environment and limits to accelerating the pace of reserve accumulation.

${ }^{1}$ Prepared by the Office of Risk Management.

\section{The projected path of precautionary balances is subject to significant uncertainty.} Projections are sensitive to assumptions about the pension-related (IAS 19) adjustment, potential new programs, and timely completion of program reviews. Weaker program performance that affects scheduled purchases and charges could slow the accumulation of precautionary balances. Further uncertainty arises from the heightened credit risks noted above and their potential impact on income. The COVID-19 pandemic has compounded these sources of uncertainty.

\section{On balance, staff believe that no additional steps are needed at this point to speed up} accumulation. Notwithstanding the continued uncertainties, a target of SDR 25 billion would be reached over the medium term under all the scenarios that allow for new demand for Fund programs beyond current arrangements. ${ }^{39}$ Given significant uncertainties, the pace of accumulation should continue to be monitored closely.

Board Decision No. 3780-(88/12), adopted on January 29, 1988). In that event, precautionary balances would decline by SDR 1.1 billion.

${ }^{39}$ A target of SDR 30 billion would not be reached in the forecasted period under the desk survey scenario. It could be reached in FY2026 under the model-based scenario consistent with the October 2020 WEO baseline and exceeded in FY2024 in the more adverse scenario. 


\section{Minimum Floor}

38. The minimum floor was increased at the $\mathbf{2 0 1 6}$ review from SDR $\mathbf{1 0}$ billion to SDR 15 billion based on both income and credit risk considerations. ${ }^{40}$ With the bulk of precautionary balances invested, they represent an important source of Fund income, and a certain minimum level of precautionary balances is consistent with a sustainable income position under the new income model. Also, Fund credit can be highly volatile and increase sharply with little notice, while it can take time to build precautionary balances. Thus, the Fund needs to maintain an adequate reserves buffer to protect against an unexpected rise in credit risks. Under the framework the floor is expected to be changed only occasionally, as it is based on longer-term considerations. In fact, the floor remained unchanged when the target was last increased in 2012.

39. Staff proposes that the floor be kept at SDR $\mathbf{1 5}$ billion for now. Given the prospects of a prolonged low interest rate environment, which will have adverse implications for future investment returns, there could be a case for raising the floor at some point to help strengthen the Fund's medium to longer-term income position in a future low credit environment. However, there is no immediate operational consequence of maintaining the floor at its current level, and therefore it may be preferable to revisit the case for an increase in the floor after the next Review of the Investment Account, currently scheduled for FY 2022.

\section{ISSUES FOR DISCUSSION}

40. Directors may wish to comment on the following issues:

- Do Directors agree with staff's assessment of the credit risks facing the Fund?

- Do Directors agree that the indicative medium-term target for precautionary balances should be raised to SDR 25 billion?

- Do Directors agree that the target needs to be monitored closely in light of developments in credit outstanding and evolving risks within the portfolio, including the largest exposures?

- Do Directors agree that it would not appear necessary at this point to take additional steps to accelerate the pace of precautionary balance accumulation, but this should be kept under close review?

- Do Directors agree that the minimum floor for precautionary balances should be kept unchanged for now at SDR 15 billion, but revisited after the next review of the Investment Account?

\footnotetext{
${ }^{40}$ See Review of the Adequacy of the Fund's Precautionary Balances (SM/16/21, 1/26/16).
} 


\section{Annex I. Overview of Other IFIs' Capital Adequacy Frameworks}

This annex updates the summary of capital adequacy frameworks in selected International Financial Institutions (IFIS) presented during the 2010-18 reviews. ${ }^{1,2}$ Most other IFIs, unlike the Fund, borrow from capital markets, and therefore in determining their approaches seek to maintain a high foreign currency long-term credit rating (AAA) by preserving a strong financial footing.

Table 1. Summary of the Capital Adequacy Frameworks in Selected International Financial Institutions (IFIs) Presented During the 2010-16 Reviews

Credit risk. The IBRD, and the ADB employ, or employed until recently, an explicit target for equity to loan types of measures. Since the global crisis, these IFIs have gradually moved towards a more comprehensive approach to assess capital adequacy though credit risks still account for the major component of required capital. In the same direction, the EBRD, AfDB, IDB, and the BIS have similar frameworks built on risk-based capital measures, where the economic capital available to support risk taking is based on an assessment of the institution's loss absorbing capacity. Available capital typically comprises paid-in capital and reserves and usually excludes callable capital. While definitions vary according to the institutions, in general, economic capital consumption is calculated by taking into account unexpected financial losses that the institution may incur subject to a targeted solvency level.
The IBRD set a target for the equity-to-loans ratio in the range of 23-27 percent in 2008. The minimum equity-to-loans ratio was reduced to 20 percent from 23 percent in FY 2014, in light of improvements in portfolio credit risk; the ratio at end-June 2019 stood at 22.8 percent. The minimum 20 percent equity-to- loans ratio is based on an internal income-based stress test that requires IBRD to hold sufficient capital to ensure that income earning capacity remains positive following a large nonaccrual shock.

The IDB had until 2009 employed a formal target for its equity-to-loans ratio of 32-38 percent. In 2010, it introduced the capital utilization ratio (CUR) as the main indicator of capital adequacy and in 2015 concluded a comprehensive review of its capital adequacy policy framework. The policy uses Capital Coverage Ratio (CCR) as the main indicator of capital adequacy. The IDB continues to publish the equity-to- loans ratio in its information statements to investors. The CCR is the ratio of adjusted equity to base capital requirements, which covers

\footnotetext{
${ }^{1}$ The International Bank for Reconstruction and Development (IBRD), the Inter-American Development Bank (IDB), the Asian Development Bank (ADB), the African Development Bank (AfDB), the European Bank for Reconstruction and Development (EBRD), and the Bank for International Settlements (BIS). Based on the latest publicly available information and Fund staffestimates.

2 The 2010 precautionary balances paper reviewed the capital adequacy practices of the IBRD, the IDB, and the ADB. The 2014 and 2016 papers summarized the overall risk management approach (capital adequacy as well as market and operational risks).
} 
Table 1. Summary of Capital Adequacy Frameworks in Selected International Financial Institutions (IFIs) Presented During the 2010-16 Reviews (continued)

financial risks, including credit, market, defined benefit pension plan, and operational risks. The CCR targets the top of a buffer zone placed on top of the minimum capital.

The ADB uses a minimum equity-to-loans ratio (ELR) target of 34 percent for long term financial planning, following the transfer of the Asian Development Fund concessional lending operation to the ADB. The ADB holds capital for credit risks and other risk exposures. Point-in-time capital adequacy is tested using a Capital Utilization Ratio (CUR) which is defined as total economic capital to total available capital. ADB is currently reviewing its Capital Adequacy Framework and is proposing to discontinue the use of the minimum ELR and use CUR as indicator of capital adequacy for both financial planning and capital adequacy test.

The EBRD's capital adequacy framework aims at maintaining the ratio of required capital (aimed at covering potential capital losses based on credit, market and operational risks) to available capital below 90 percent. Required capital varies by product and counterparty rating in the banking book. Overall internal capital requirements are calibrated relative to external benchmarks: the Basel capital framework and rating agency frameworks.

The AfDB's economic capital framework, which is enshrined in its risk appetite statement, caps the ratio of required risk capital to available risk capital at 100 percent with a recapitalization trigger at 90 percent. Economic capital for credit and market risk (including the pension benefits plan) is determined using a value-at-risk model and incorporate balance sheet optimization operations. Capital for operational risks is based on a basic indicator approach. The AfDB's risk capital utilization rate (RCUR) was about 77 percent at end-June 2019, of which the bulk was reserved for credit risks.

The BIS's economic capital framework which covers credit risk, market risk and operational 
Table 1. Summary of Capital Adequacy Frameworks in Selected International Financial Institutions (IFIs) Presented During the 2010-16 Reviews (continued)

\begin{tabular}{|c|c|}
\hline & $\begin{array}{l}\text { risks, is geared to a higher solvency level than the } \\
\text { minimum Pillar } 1 \text { capital level required. The } \\
\text { framework was reviewed recently. As of April 2019, } \\
\text { risk-bearing capacity is defined as the BIS's } \\
\text { Common Equity Tier } 1 \text { (CET1) capital. Economic } \\
\text { capital for credit risk is determined on the basis of } \\
\text { a portfolio value-at risk model. In addition, the BIS } \\
\text { maintains a "minimum capital cushion" of } 15 \\
\text { percent of CET1 capital with a view to sustaining a } \\
\text { potential material loss without the need to reduce } \\
\text { other capital allocations or liquidate assets. }\end{array}$ \\
\hline $\begin{array}{l}\text { Market risks. Treatment of market risks in the IFIs' } \\
\text { capital adequacy frameworks varies. Several IFIs } \\
\text { have integrated market risks in their capital } \\
\text { frameworks, although the specific risks covered } \\
\text { and the amount of allocated capital vary } \\
\text { considerably. }\end{array}$ & $\begin{array}{l}\text { The IBRD minimum equity-to-loans ratio of } 20 \\
\text { percent includes a buffer for market risks. } \\
\text { The ADB's capital metrics mentioned above } \\
\text { include the capital required for equity investment } \\
\text { risk, interest rate risk, currency risk, and pension- } \\
\text { related market risk. } \\
\text { The IDB manages overall interest rate risk through } \\
\text { setting a target for equity duration. In addition, it } \\
\text { sets a risk appetite for its investment portfolio as } \\
\text { measured in the form of value-at-risk. The CCR } \\
\text { quantifies capital requirements for interest rate risk } \\
\text { on the whole bank balance sheet (including its } \\
\text { pension plans) and for foreign exchange risk. } \\
\text { Capital requirements for market risk are } \\
\text { aggregated with those of other financial risks } \\
\text { through the use of a correlation matrix. } \\
\text { The AfDB sets the maximum economic capital for } \\
\text { all non-core risks (market, operational and pension } \\
\text { plan) at } 10 \text { percent of total available capital. At } \\
\text { end-June } 2019 \text {, about } 9.6 \text { percent of the AfDB's } \\
\text { economic capital was reserved for non-core risks } \\
\text { including interest rate, currency, liquidity and } \\
\text { counterparty credit risks as well as residual risk } \\
\text { exposures to its staff retirement plan. } \\
\text { The EBRD operates within Board-approved limits } \\
\text { for market risk on treasury and banking debt assets } \\
\text { based on value-at risk approach. Minimum capital } \\
\text { requirements for treasury activities (credit and } \\
\text { market risk) are set at five percent of the } \\
\text { investment portfolio. }\end{array}$ \\
\hline
\end{tabular}


Table 1. Summary of Capital Adequacy Frameworks in Selected International Financial Institutions (IFIs) Presented During the 2010-16 Reviews (concluded)

\begin{tabular}{|c|c|}
\hline & $\begin{array}{l}\text { The BIS determines the economic capital for } \\
\text { market risk on the basis of a value-at risk modelling } \\
\text { based on stressed market data. }\end{array}$ \\
\hline $\begin{array}{l}\text { Operational risks. All IFIs give priority to the } \\
\text { management of operational risk through strong } \\
\text { internal controls. With regard to capital adequacy, } \\
\text { the treatment of operational risks varies across IFIs. }\end{array}$ & $\begin{array}{l}\text { For the IBRD, the minimum equity-to-loans ratio } \\
\text { of } 20 \text { percent includes a buffer for operational risks. } \\
\text { The ADB's capital requirement for operational risk } \\
\text { is set at } 1 \text { percent of total assets in the balance } \\
\text { sheet. Off balance sheet commitments and } \\
\text { undisbursed loans and guarantees are considered } \\
\text { in the calculation of total assets. ADB is currently } \\
\text { reviewing its Capital Adequacy Framework and is } \\
\text { proposing to reduce the capital requirement set } \\
\text { aside for operational risk. } \\
\text { The IDB allocates capital of one percent of total } \\
\text { assets to operational risks. Capital requirements for } \\
\text { operational risk are aggregated with those of other } \\
\text { financial risks through the use of a correlation } \\
\text { matrix. } \\
\text { The AfDB's capital adequacy framework provides } \\
\text { for an operational risk capital charge based on } \\
\text { Basel II of } 15 \text { percent of the average operating } \\
\text { income for the preceding three years. At end-June } \\
2019 \text {, about } 0.9 \text { percent of the AfDB's economic } \\
\text { capital was reserved for operational risks. } \\
\text { The EBRD's required capital takes operational risks } \\
\text { into account consistent with Basel II, using a capital } \\
\text { change of } 15 \text { percent of the average operating } \\
\text { income for the preceding three years. } \\
\text { risks on the basis of a value-at risk approach that is } \\
\text { consistent with the methodology set out in the } \\
\text { Basel II advanced measurement approach. The } \\
\text { methodology is currently under review with the } \\
\text { objective of moving towards an approach based on } \\
\text { the new Basel III Standardized Approach. }\end{array}$ \\
\hline
\end{tabular}




\section{Annex II. Demand for New Programs}

This annex explains the methodology used to estimate the potential demand for new Fund credit in 2020-21 under a scenario consistent with the October 2020 WEO and high financial market volatility, reflecting the COVID-19 pandemic. It shows that under the baseline global outlook, the outstanding stock of Fund credit from new programs would increase significantly, adding around SDR 76 billion at its peak to the projected stock from existing arrangements, including recently approved emergency financing. As a result, precautionary balances could surpass the current indicative target in FY 2023, and could reach nearly SDR 32 billion over the medium term.

\section{The analysis uses a panel logit regression to identify countries that are likely to tap} IMF resources under the General Resources Account (GRA). ${ }^{1}$ Drawing from the literature, the model relates the probability of entering a new Fund arrangement to global and country-specific determinants. The sample covers 96 advanced, emerging and frontier market economies over the period 1992-2018, and 104 GRA arrangements. Estimated results suggest that the probability of a country requesting Fund support increases with higher external financing needs, higher financial market volatility, tighter global financial conditions, and lower GDP growth, among other factors (Table 1). A threshold for the probability of entering a program is then determined by minimizing the weighted average of missed new programs (Type I error) and false alarms (Type II error) for the in-sample forecasts. Under the assumption of equal weights for Type I and Type II errors (i.e., a 1:1 ratio), the threshold is found at 3.7 percent. ${ }^{2}$ Using this threshold, the model correctly identifies 95.4 percent of new programs over the period 1992-2018 (Table 2).

\section{Estimated results are then used to predict the probability of sample countries} entering an IMF program in FY 2021 and FY 2022. The analysis uses the October 2020 WEO baseline data for each sample country for the next two years, and the 2020 year-to-date average VIX level of 31, to reflect the global economic outlook and financial market conditions. A country is assumed to enter in a new IMF program if its predicted probability exceeds the 3.7 percent threshold in a given year. Under this approach, 46 countries are predicted to enter a new Fundsupported programs, of which 29 are assumed to come forward in FY 2021-22, based on staff analysis. $^{3}$

\footnotetext{
${ }^{1}$ Consistent with ORM-SPR-FIN Outlook-for-Potential-Programs (OPP) exercise.

2 Type I error represents the ratio of actual new programs that the model failed to predict to total new program observations, while Type II error refers to the ratio of predicted programs that did not occur to total non-program observations. Higher thresholds of 6.8 and 16.4 percent are identified when Type I and Type II errors are minimized in the ratios of 2:1 and 3:1, respectively, as such an approach penalizes false alarms more and flags fewer countries requesting Fund's program.

${ }^{3}$ Staff assessed members' probability to request Fund financial support, taking into account whether potential borrowers had already active precautionary and non-precautionary arrangements with the Fund, whether they had access to markets or other financing sources (e.g., through regional facilities), and whether they were eligible to obtain Fund credit under current policies.
} 
3. The potential call on Fund resources would be high consistent with a severe economic fallout from the COVID-19 Pandemic. Access is calculated using the average size of Fund programs (excluding precautionary arrangements as they are not part of the forwardlooking credit measure for the indicative target range ) in the past ten years of about 5 percent of GDP, and in each identified case adjusting for outstanding Fund credit, projected disbursements and repurchases consistent with applicable exceptional access limits. On this basis, aggregate new demand for IMF financing under 29 disbursing arrangements could reach about SDR 138 billion over FY 2021-2022.

\section{Under this WEO model-based scenario, the outstanding stock of Fund credit is projected to increase over the stock resulting from existing arrangements by about} SDR 76 billion at the peak in FY 2024. A combination of 10 Stand-By Arrangements (SBAs) and 19 Extended Fund Facilities (EFFs) is assumed, with even phasing over three years for SBAs and four years for EFFs. The average outstanding stock of Fund credit is projected to rise from about SDR 67 billion in FY 2020 to a peak of SDR 164.8 billion in FY 2024 (Figure 1), including existing arrangements and prospective arrangements under this baseline scenario. This compares with a peak of SDR 88.5 billion if only existing arrangement are taken into account.

\section{As a result of projected new arrangements, precautionary balance would surpass the indicative target by FY 2023, and reach nearly SDR 32 billion over the medium term.} This is higher than projections based only on existing arrangements, where precautionary balances would reach the indicative target by FY 2023, and remain close to the target level over the medium term.

\section{Additional demand for Fund resources over this baseline could materialize in a} more adverse scenario. Given the uncertain global economic outlook in the wake of the pandemic, staff considered an adverse scenario where the projected growth for 2020-21 for a country is assumed to fall by $1 / 2$ standard deviation of its historical values relative to the October 2020 WEO baseline. The growth shock is combined with a high financial market shock (VIX level of 40). In addition, it is assumed that (1) average access per arrangement is significantly higher than under the baseline, about 7 percent of GDP (excluding precautionary arrangements) and that (2) all current FCL arrangements are drawn simultaneously. As a result, the outstanding stock of Fund credit is projected to increase by about SDR 137 billion above the peak under the WEO model-based scenario. The impact on Fund credit could thus be illustrative of a second wave of the pandemic. In this scenario, precautionary balances would increase to SDR 46 billion over the medium term. 


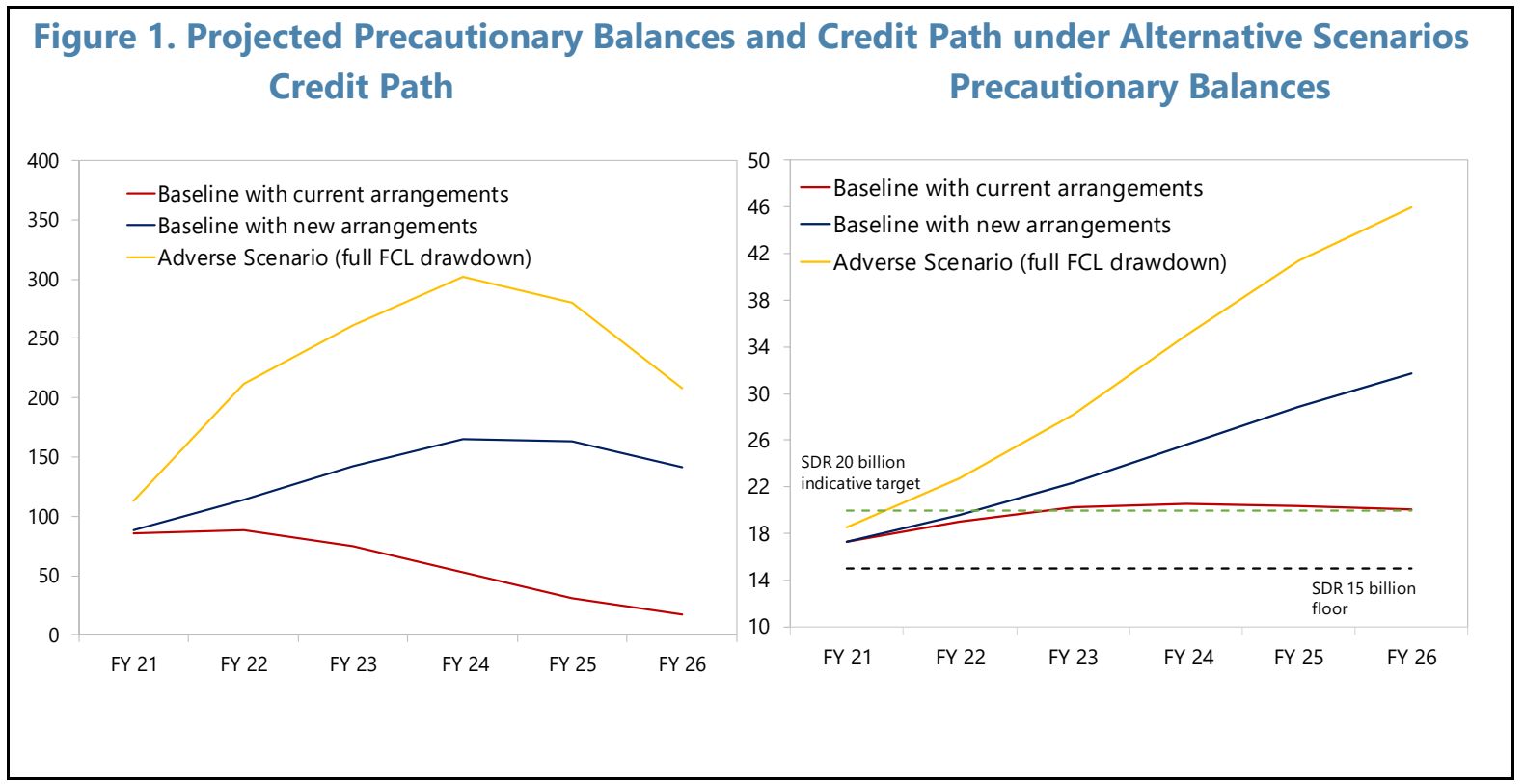

Table 1. Model Output

Logit Estimation Results

Dependent variable: Start of a GRA Arrangement (dummy)

\begin{tabular}{lrrr}
\hline Independent Variables & $\mathrm{dy} / \mathrm{dx}$ & Robust SE & P-value \\
\hline \hline Past program (dummy) & $0.405^{\star \star *}$ & 0.067 & 0.000 \\
Reserve accumulation & $-0.0745^{\star \star}$ & 0.034 & 0.027 \\
External Financing Needs & $0.651^{\star *}$ & 0.304 & 0.033 \\
GDP growth & $-0.0902^{\star \star \star}$ & 0.027 & 0.001 \\
GDP per capita & $-1.026^{\star \star *}$ & 0.192 & 0.000 \\
GDP & 0.0115 & 0.108 & 0.915 \\
Credit gap & $0.0221^{\star *}$ & 0.009 & 0.019 \\
Exchange rate variation & -0.376 & 0.398 & 0.344 \\
Government stability & $-0.322^{\star \star *}$ & 0.076 & 0.000 \\
3M US int. rate variation & 0.123 & 0.127 & 0.332 \\
Import coverage & $-0.106^{\star *}$ & 0.047 & 0.023 \\
VIX & $0.0808^{\star * *}$ & 0.027 & 0.003 \\
Oil price & -0.0053 & 0.006 & 0.410 \\
Access to RFA (dummy) & 0.236 & 0.305 & 0.439 \\
\hline Pseudo R2 & 0.465 & & \\
Observations & 2,026 & & \\
Countries & 96 & & \\
GRA Arrangements & 137 & & \\
Likelihood ratio (p-value) & 0.002 & & \\
\hline
\end{tabular}

Notes: the table reports the marginal effects of the panel logit estimation using random effects. A constant is estimated but not reported.

$\star \star \star, * *$, and ${ }^{\star}$ denote significance at the 1,5 , and 10 percent levels, respectively. 


\section{Annex III. Burden Sharing Capacity}

This annex discusses the role of the Fund's burden sharing mechanism as well as the factors that determine its capacity. It observes that, despite an improvement since the last review in 2018, the current burden sharing capacity provides only a limited buffer relative to scheduled charges falling due under the Fund's exposures.

\section{Role of the Burden Sharing Mechanism}

1. The burden sharing mechanism was established in $\mathbf{1 9 8 6}$ to compensate the Fund for any unpaid charges by members in arrears ("deferred charges"), and in so doing, to offset the impact of unpaid charges on Fund income. Under burden sharing, the Fund's creditor and debtor members contribute temporary financing in equal amounts to cover the amount of unpaid charges. This is achieved through increases in the rate of charge paid by debtor members and reductions in the rate of remuneration to creditor members. ${ }^{1}$

\section{The burden sharing mechanism has proven important in protecting the Fund's income position and in enabling the Fund to recognize no impairment for its credit outstanding under International Financial Reporting Standards (IFRS). Specifically, even though a member may not be meeting its obligation to pay charges, the collection of an equivalent amount from other members through the burden sharing mechanism enables the Fund to demonstrate that, on a net present value basis, there is no impairment of outstanding credit under the IFRS.}

\section{Should the loss of income from deferred charges exceed the capacity of the} mechanism, the carrying value of the asset in arrears on the Fund's balance sheet may need to be reduced. The deferred charges in excess of the burden sharing capacity would reduce the Fund's annual net income and reduce the pace of accumulation of precautionary balances. Moreover, future cash flows due from members in arrears would not be expected to be collected in full, which could undermine the Fund's ability to demonstrate that the carrying value of credit outstanding has not been impaired, giving rise to the possibility of an impairment loss. ${ }^{2}$ Recognition of an impairment loss arising from deferred charges would need to consider a variety of factors, including the unique nature of the Fund's financing mechanism, but could have a further negative impact on the Fund's net income and precautionary balances. ${ }^{3}$

\footnotetext{
${ }^{1}$ These adjustments are currently set to match charges in arrears but could also include the possible accumulation of balances in the SCA-1, which are part of precautionary balances. Accumulations to the SCA-1 were suspended effective of November 1, 2006, due to high projected adjustments to the rates of charge and remuneration in a low and concentrated credit environment.

2 Under IFRS, the amount of the loss is measured as the difference between an asset's carrying amount and the present value of estimated future cash flows.

${ }^{3}$ Recognition of an impairment loss is not equivalent to writing off the outstanding claims against the member in arrears, since it does not relieve the member of its obligations to the Fund. The impairment loss may be reversed in future years as the arrears are cleared.
} 


\section{Capacity of the Burden Sharing Mechanism}

4. The total capacity of the burden sharing mechanism to cover unpaid charges is the sum of the maximum feasible reduction in remuneration expenses and the maximum feasible increase in income from charges:

- Article V, Section 9 (a) of the Fund's Articles of Agreement states that the rate of remuneration shall be no less than four-fifths ( 80 percent) of the SDR interest rate, limiting the maximum reduction in remuneration expenses to: 0.2 * SDR Interest Rate * Remunerated Reserve Tranche Positions. The Board has set the current floor for remuneration at 85 percent of the SDR interest rate, which may be changed with a 70 percent majority of the total voting power. $^{4}$

- The maximum capacity of a symmetrical burden sharing mechanism is simply twice the above amount, because debtors and creditors contribute equally. ${ }^{5}$ However, the contributing debtor base declines in the event of arrears, which may in practice limit the maximum feasible adjustment to the rate of charge without overburdening these members.

\section{The burden sharing capacity depends on the following factors: 6}

- Quotas payments: quota increases typically result in higher reserve tranche positions, as members acquire additional liquid claims on the IMF as part of their quota payments. ${ }^{7}$ As reserve tranche positions increase, the remunerated portion also increases, thus allowing for a larger maximum reduction in remunerated expenses and higher burden sharing capacity. Remunerated reserve tranche positions have increased from SDR 40 billion at the end of 2017 to about SDR 92 billion in August 2020.

- Outstanding credit and borrowing by the Fund: Reserve tranche positions also move in tandem with changes in outstanding credit financed from quota resources. However, no burden sharing adjustment is made to the interest paid to creditors on borrowed resources (New Arrangements to Borrow and bilateral loan or note purchase agreements). Therefore, outstanding credit financed by borrowed resources would not affect the Fund's burden sharing capacity.

\footnotetext{
4 See Decision No. 12189-(00/45), April 28, 2000, as amended.

${ }^{5}$ Under the terms of the burden sharing Decision No. 11945-(99/49), adopted April 30, 1999, the operation of the mechanism would need to be reviewed if the adjustment in the rate of remuneration falls below the agreed floor of 85 percent of the SDR interest rate. Absent any Executive Board decisions at such a review, debtor members would be required to cover any remaining amounts of unpaid charges through further (uncapped) adjustments to the rate of charge, and burden sharing would become asymmetric.

${ }^{6}$ Burden sharing capacity can also be affected by other Fund operations and transactions involving changes in the GRA currency holdings, such as transfer of currencies to the Investment Account and sales of SDRs to members in exchange for currencies.

${ }^{7}$ Quota increases paid in currencies do not affect members' aggregate RTP positions.
} 
- SDR interest rate: as the burden sharing adjustment to the rates of remuneration is set as a proportion of the SDR interest rate, a higher SDR interest rate increases the total burden sharing capacity. As of end-August 2020, the SDR interest rate was at 0.091 percent, compared to the 0.733 percent SDR interest rate as of end-November 2017.

6. The burden sharing capacity has decreased since the $\mathbf{2 0 1 8}$ precautionary balance review primarily owing to the drop in the SDR rate. As of end-August 2020, the annual burden sharing capacity (based on the current floor for remuneration at 85 percent of the SDR interest rate) was about SDR 25 million, compared to just over SDR 86 million at the end of 2017. After accounting for deferred charges by Sudan, the residual burden sharing capacity is at around SDR 23 million, compared to under SDR 82 million at the end of 2017.

\section{Figure 1. Burden Sharing Capacity 2005-20201/}

(In millions of SDRs)

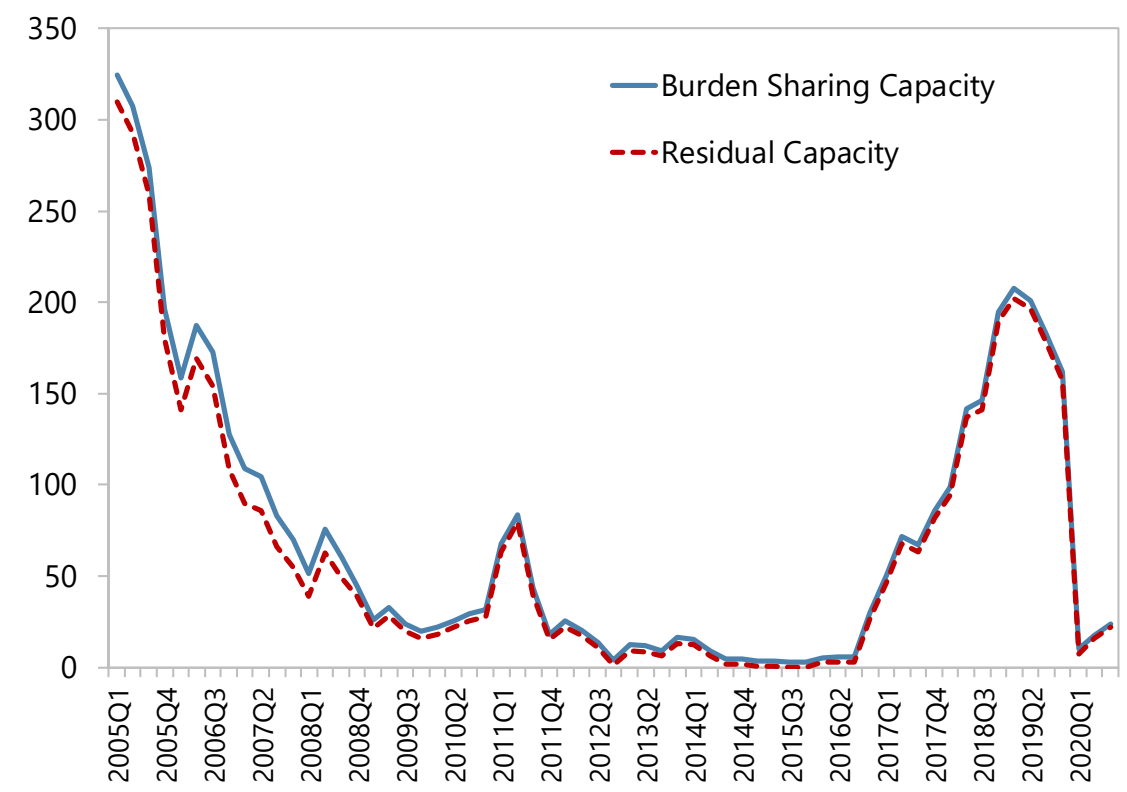

Source: Finance Department.

${ }^{1}$ Under a floor for remuneration of 85 percent of the SDR interest rate. 


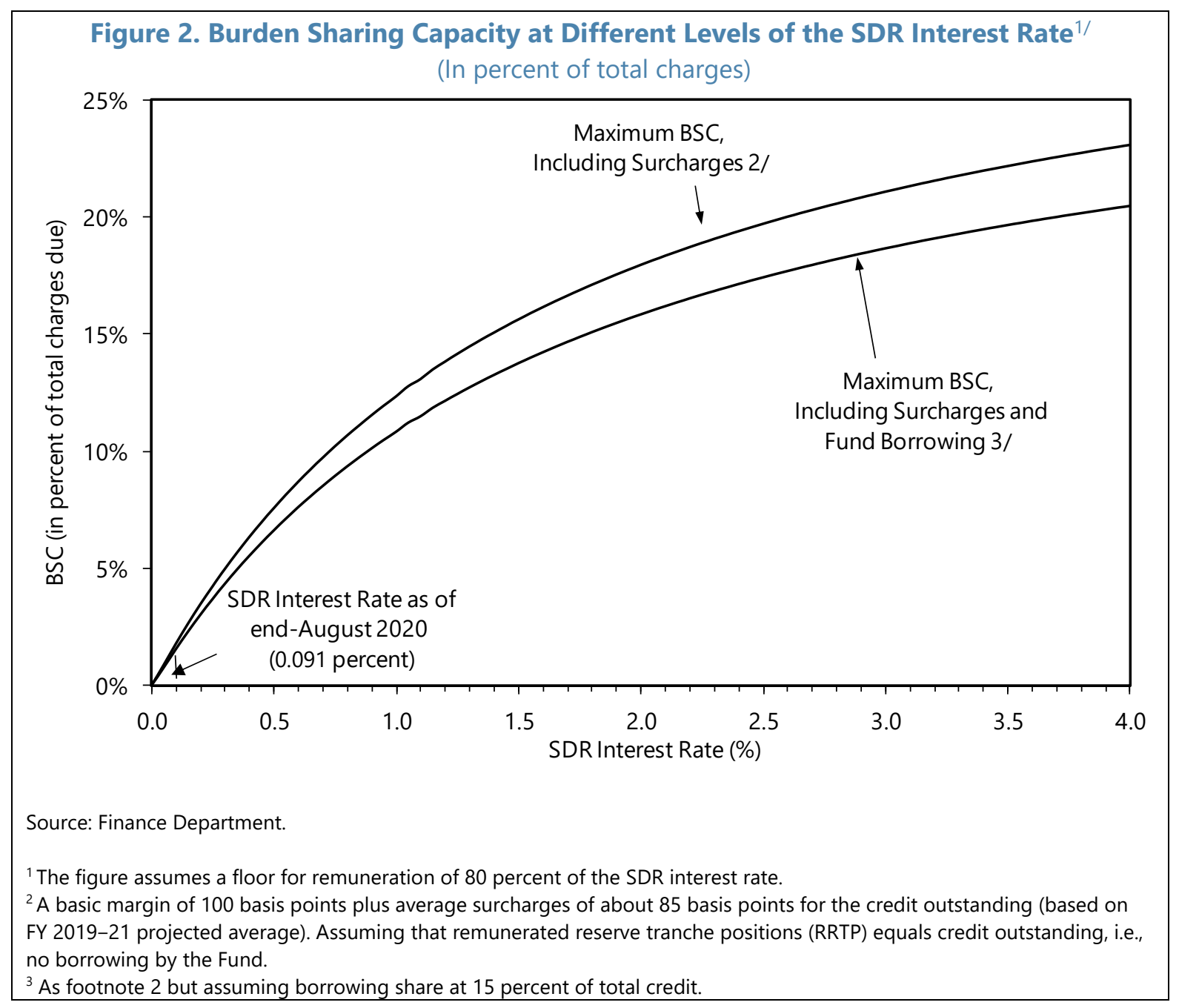

